\title{
DETERMINANTS OF THE IMPLEMENTATION OF INFORMATION AND COMMUNICATION TECHNOLOGIES IN CLUSTERS OF ENTERPRISES
}

\author{
Zora Arsovski* \\ Faculty of Economics, University of Kragujevac, Kragujevac, Serbia
}

The implementation of Information and Communication Technologies (ICT) in enterprises organized as part of a cluster has its own specifications according to the level and type of relations between enterprises in the cluster. The purpose of this paper is to define determinants for the quality of the ICT implementation in clusters, the research goal being to define and validate the quality models of the implementation of ICT in clusters. Based on the theoretical research of clusters, the quality model for the ICT implementation has been developed and tested to the influences of the determinants of the implementation of ICT, which refer to the level of investments in ICT, quality management, the quality of processes and the level of the implementation of the ICT strategy at the level of the quality of the ICT implementation, with the confirmation of the significance of the stated hypothesis. The results of the research indicate the fact that the level of the quality of the ICT implementation could be predicted with a high accuracy, as well as the influence of the performances of enterprises and the cluster as a whole.

Keywords: Information and Communication Technologies, the cluster of enterprises, determinants, quality

JEL Classification: M15, L15, P13, R19

\section{INTRODUCTION}

In this time of globalization, it is evident that ICT has a rapid development and implementation in all segments of human society, so the concept of a digital economy, e-economy and information society is evident in the literature and practice. According to E. Turban et al (2006), goals of the implementation of ICT could be addressed from strategic, tactical and operative aspects in the following fields:

\footnotetext{
* Correspondence to: Z. Arsovski, Faculty of Economics, University of Kragujevac, Dj. Pucara 3, 34000 Kragujevac, Serbia; e-mail: zora@kg.ac.rs
}

- Business cooperation (supply chains, clusters, networks, virtual enterprises),

- E-business,

- Business Process Management - BPM,

- Business Process Reengineering - BPR, and

- Constant improvement of quality, productivity, agility, flexibility and other business performances in enterprises and different forms of business.

The analyses of the usage of the ICT resources in the USA show that, annually, enterprises make more than $50 \%$ of all their investments and invest about $4.2 \%$ of their annual income in ICT (Weil \& Ross, 2004). 
The management of enterprises are under constant pressure to reduce expenses and increase the value of ICT resources, which has the function of improving performances of the system, increasing the quality of services and products, internal and external communications, and improving relations with customers and suppliers.

Clusters are a form of organization of different enterprises, in a specific territory, with specialized suppliers, service providers, and enterprises and institutions accompanying them. The advantages of the clusters are numerous:

- An increased level of knowledge achieved through cooperation and learning among the members of the clusters,

- The development of complementary knowledge and skills in the function of the increased competitiveness of the cluster,

- An achieved economy of scale,

- The improvement of social and other informal connections,

- The improvement of flows between the members of the clusters,

- A faster development of new products,

- The improvement of the accompanying infrastructure, etc.

In this paper, the research is directed towards the implementation of ICT at the level of enterprises connected in clusters, where communication problems and decision making among enterprises in the clusters are identified. On the other hand, the value of networked enterprises increases with the number of included enterprises, which increases the number of communications influencing the quality of the decisions made by the users of the network, the performances of the network and the cluster as a whole.

The purpose of this paper is to define the determinants of the quality of the implementation of ICT in enterprises organized in a cluster. The organization of clusters becomes more and more common, especially in small and medium-sized enterprises, where cooperation is predominantly based on the implementation of ICT. Besides, the quality of ICT implementation solutions is highly important for the successful business performances of enterprises.

For the purpose of determining the quality of ICT implementation in clusters, a cluster with a complex structure, a high level of the geographical distribution of enterprises, is analyzed where enterprises are of different sizes, structures and maturity, where enterprises work in different sectors (the food processing, tourism, services, and other industrial sectors), and have different implementations of ICT solutions and different levels of the implementation of ICT. For the selected cluster, the determinants of the quality of ICT solutions are analyzed, where the determinants were identified through an analysis of the reference literature. The following determinants of the quality of the implementation of ICT solutions were identified through the analysis: (1) the level of investment in ICT, (2) the quality of the management, (3) the level of the quality of the processes and (4) the level of the quality of the ICT strategy.

The research into the implementation of ICT in enterprises covers theoretical and empirical researches with the implementations of the methods and concepts of a system approach, the theory of constraints, goaloriented management, the quality, modeling and implementation of ICT, the theory of organizations and the theory of clusters. The applicative researches are realized by using methods and tools for the conceptual design of models, the design and analysis of the questionnaires and the implementation of the statistical methods supported by ICT.

The results of the researches have both a theoretical and an empirical character. As the result of the theoretical research, the quality model of the implementation of ICT in a cluster is presented. The empirical results of the researches are presented at the defined level of the influences of the determinants (variables in this model) on the quality of the implementation of ICT solutions and an average level of the determinants of the quality of ICT implementation.

The practical implementations of the presented researches for the selected cluster and other clusters are: (1) the determination of the level of the 
determinants of the implementation of ICT in the Republic of Serbia (RS), (2) the determination of the influence of the variables in the model on the quality of ICT solutions and (3) an extension of the model by identifying a possibility for additional variables.

Based on the results of the theoretical researches, and presenting the results of the developed model of the quality of the implementation of ICT as well as those of the collected data from the selected cluster, a statistical analysis was performed confirming the defined hypothesis. The key hypothesis has especially high significance; it represents the synergic effect of the variables in the model of the quality of the implementation of ICT solutions. All of these help to make a highly reliable prediction for the level of the quality of ICT implementation as well as for the influence of the implementation of ICT on the key performances of the enterprises in the cluster.

The paper is structured into five sections. After the introduction, the second part deals with an overview of the literature relevant for the definition of the key determinants of the quality of the implementation of ICT solutions. The definition and development of a model for the quality of the implementation of ICT solutions and the theoretical background for the definition of an additional (working) hypothesis are presented in the third section. The structure of the sample and the statistical analysis of the results are accounted for in section four. In this section, the relations in the developed model, their graphical interpretation pointing to the significance of the relations in the model are demonstrated. The final section is the presentation of the conclusions referring to the validity of the stated hypothesis and the directions for a further research.

\section{A REVIEW OF PREVIOUS RESEARCHES}

The quality of the implementation of ICT solutions is based on the synergic effect of the quality of information based on the implemented ICT solutions (Laudon \& Laudon, 2012; Cragg, 2008; Ngwenyama, \& Morawczynski, 2009; Tanriverdi, 2006), the quality of the functioning of ICT (Martin et al, 2011; Cragg, 2002) and the satisfaction of internal and external ICT users
(Chen et al, 2011; Cragg et al, 2002; Franke \& Preifer, 1998). For a valid identification of the determinants of the quality of the implementation of ICT, the relevant literature in the field of process modeling is used (Albright et al, 2011; Casadeus-Masanell \& Ricart, 2009; Gadatsch, 2005; Sanders \& Premus, 2005; Becker, 2003; Scheer, 1999), ICT (Tonchia \& Tramontano, 2004; Prytibok et al, 2008), quality (Harton et al, 2010; Oukland, 2004; Gadatsch, 2005; Evans, 2011) and clusters (Leidner \& Preston, 2011, Iammarino \& McCann, 2006; Gordon \& McCan, 2005).

The research problem of this paper is of an inter- and multidisciplinary nature. In the reference literature in this field, the most predominant papers are related to the field of supply chains and e-government. In their paper V. Prytibok, X. Zhank and S. Ryan (2008), the quality of ICT is analyzed in e-government, where leadership is observed as a determinant, and a gross benefit is observed as a goal function. The hypothesis that the quality of ICT has a positive influence on a gross benefit is proved on the example of an e-government with 339 questionnaires.

In their paper, A. S. Brah and H. Y. Lim (2006) it was shown that ICT is connected with quality. The authors divided business performances into three groups: operative performances (such as costs, cycle time), quality performances and technology performances (such as ICT performances). A relatively high level of influence of ICT on strategic planning (0.715) as well as customer orientation (0.636) was reported.

The security risk of information in e-government (Berghmans \& Roy, 2011) is very important. So, the implementation of ICT has to cover this aspect, which is included through risks at a strategic and tactical level, while the risks of ICT implementation are presented through the quality of information and the quality of ICT functioning. In clusters, these risks are considerably lower than those implementation risks of ICT in e-government, so they could be excluded from the analysis in the first iteration.

The second very important group of problems refers to the ambiguity of the environment. D. Mirchandani and A. Lederer (2012) analyzed the planning of an information system in an ambiguous environment. The contribution of IS is presented through the 
adjustment of ICT to the business needs and risks and the achievement of the growth of competitiveness through utilizing ICT.

In clusters, the members of a different ICT were implemented with different levels of maturity. A. Ragovsky, P. Licker and D. Gafen (2012) analyzed this problem from the aspect of the influence of ICT on organizational efficiency and the creation of a new value using ICT. They marked the five levels of maturity and for each level, they defined the characteristics of ICT having an influence on members and clients, e.g. organizations (enterprises) - members of the clusters.

For each cluster member and cluster as a whole, the important aspects in functioning are information collecting and utilizing it in a business strategy. In their paper E. Mc Fadzean, J. Ezingeard and D. Birschall (2011), the authors analyzed the alignment of information assurance and the business strategy. They defined a model for gathering information for business strategies with options for the improvement of information alignment with a business strategy.

In their paper N. Chen, M. Elnaghi and T. Harzakis (2011), the factors of knowledge management with the influence of the performances of ICT in organizations in China are analyzed. In their model, one of the variables (V6) is ICT, with a significant influence on organizational performances (influence factor 0.787 ).

P. Morosini (2004) identified five key aspects necessary for the achievement of a mutual value:

- Leadership at the level of enterprises and the cluster,

- Mutual elements (behavior, language, culture, talents, specializations, business understanding, measurement of specific performances),

- Communication rituals (events, interactions),

- Connection of knowledge, and

- Professional rotation in enterprises in clusters.

In his paper, P. Morosini (2004), the role of leadership and mutual elements in the determination of leaders in clusters and the acceptance of leaders by all the members of such clusters are especially emphasized.
Leadership in clusters covers the coordination of the share of knowledge, the education of the future leaders of enterprises and clusters, and arbitration, the development of a vision and change management.

According to I. R. Gordon and P. McCann (2005), there are three groups of industrial clusters:

- Clean agglomerations,

- Industrial complexes and

- Social networks.

In the first case, the relations between enterprises are more or less transient, they are separate and do not have a market power, so they try to achieve this through clusters. As a result, there is no loyalty between them or any long-term relations. In an industrial complex, there are long-term and stable relations between enterprises in the clusters, based on the final product (e.g. the automotive and chemical industries). Members of clusters get together in order to improve long-term investments and minimize transportation costs among them. The third group of clusters are social networks based on the development of a relation of trust for mutual decision making in enterprises in clusters. It reduces transactional costs among them.

According to Rosenfeld (2002), clusters have the following characteristics:

- Systematic connections between enterprises,

- Interconnection of enterprises in specific geographical areas,

- The life cycle (the embryonic stage, growth, maturity, reduction and death),

- Change of members (enterprises),

- Production, and

- Relation between enterprises.

One of the key characteristics of clusters is relations between members of clusters (enterprises) needing networking through ICT because of the geographical location.

C. Wagner (2004) points to changes in the definition of the strategy in the 21st century: (1) the shorter cycles of planning and changes, (2) changes in enterprises occurring more often, frequently with discontinuity 
and (3) the inclusion of the parts of enterprises in supply chains and virtual enterprises. In these new conditions, it is necessary that an appropriate information system covering and supporting all the four phases in the management maturity model should be developed: financial plans, planning based on prediction, externally-oriented planning and strategic management.

Software for supporting strategic management is based on an ERP (Enterprise Resource Planning - ERP) solution including BSC (Balanced Score Card - BSC), EPM (Enterprise Performance Management - EPM) software and ESE (Enterprise Strategy Execution Cycle - ESE) software.

Competences are connected with human resources, which, according to the resource-based theory, have an influence on business performances. Resources connected with ICT could be divided into three groups:

- Tangible resources (e.g. a physical infrastructure for ICT, )

- Human resources for ICT (technical ICT knowledge, managerial ICT knowledge) and

- Non-tangible ICT resources (knowledge, customer orientation and synergy).

J. Peppard and J. Ward (2004) identified six domains of competences with 26 types of competences connected with ICT (Table 1).

In Table 2, ICT competences for different types of managerial practice are separated (Cragg, 2008, 32).

The third group of ICT competences are connected with key technical practice (Table 3), (Cragg, 2008, 33).

In his paper, H. Tanriverdi (2006), the role of ICT resources and management practice are analyzed as a source of synergy between business units of enterprises. The synergy of business units of enterprises is achieved by supporting an appropriate ICT infrastructure, the realization of the process of the development of an ICT strategy, the management of the relations connected with the implementation of ICT and the management process of ICT resources. The author presented the results of the researches conducted on a sample of 165 industrial and 191
Table 1 ICT competencies

\begin{tabular}{ll}
\hline Competency Domain & \multicolumn{1}{c}{ ICT competencies } \\
\hline Formulate strategy & Business strategy \\
& $\begin{array}{l}\text { Technology innovation } \\
\text { Investment criteria } \\
\text { Information governance }\end{array}$ \\
\hline & Prioritization \\
& ICT strategy alignment \\
Definition of the ICT & Business process design \\
strategy & Business performance improve- \\
& ment \\
& Systems and process innovation \\
\hline \multirow{2}{*}{ Define ICT perfor- } & Infrastructure development \\
mances & Technology analysis \\
& Sourcing strategy \\
\hline \multirow{3}{*}{ Exploitation } & Benefits planning \\
& Benefits delivered \\
& Managing change \\
\hline Supply & Applications development \\
& Service Management \\
Information asset management & Implementation Management \\
& Apply technology \\
& Business continuity and security \\
\hline Deliver solutions & Supplier relationships \\
& Technology standards \\
& Technology acquisition \\
& Asset and cost management \\
& ICT staff development \\
\hline
\end{tabular}

Source: Peppard \& Ward, 2004, 178-179

service enterprises $(\mathrm{N}=365)$, showing that - between the selected variables - there is a high correlation with the quality of ICT implementation (the factors ranging from 0.76 to 0.90 ), while the influence of the implementation of ICT on the performances of an enterprise is significantly lower (0.12). In this paper, the model of the management of ICT resources is accounted for, based on the resource-based theories. The author starts from the strategy only to be followed by the definition and purchase of the needed ICT solutions. After the delivery of ICT solutions, their practical implementation is observed; finally, the contribution of ICT to the fulfillment of the strategy is evaluated. At the level of human resources, connected with different roles, business, skills, knowledge and 
Table 2 Key managerial factors and comparative ICT competences

\begin{tabular}{|c|c|c|}
\hline Key managerial practice & Practice Description & Related ICT competencies \\
\hline $\begin{array}{l}\text { Role of ICT within the } \\
\text { business }\end{array}$ & $\begin{array}{l}\text { In leading enterprises, ICT was viewed as stra- } \\
\text { tegic and provided a considerable advantage } \\
\text { over competitors. In inflexible enterprises, ICT } \\
\text { to participate in the implementation process, } \\
\text { but not over the competitors. Other enterpris- } \\
\text { es use ICT at the operational level. }\end{array}$ & $\begin{array}{l}\text { - Business strategy (providing the use of ICT } \\
\text { opportunities). } \\
\text { - ICT strategy alignment (providing the condi- } \\
\text { tions that ICT plans to integrate its strategic } \\
\text { plan of the enterprise with). }\end{array}$ \\
\hline $\begin{array}{l}\text { Senior management } \\
\text { commitment to ICT }\end{array}$ & $\begin{array}{l}\text { The senior managers of leading enterprises are } \\
\text { enthusiastic regarding the use of ICT and taking } \\
\text { responsibility for ICT projects. In other enter- } \\
\text { prises, they ignore all the ICT requirements of } \\
\text { a crisis. }\end{array}$ & $\begin{array}{l}\text { - Benefits planning from investments in ICT. } \\
\text { - Managing change (business and organiza- } \\
\text { tional changes are implemented in order } \\
\text { to maximize benefits without impacting on } \\
\text { stakeholders). }\end{array}$ \\
\hline $\begin{array}{l}\text { Managers see new uses for } \\
\text { ICT }\end{array}$ & $\begin{array}{l}\text { In the leading enterprises, strategic manag- } \\
\text { ers are able to use ICT through internal and } \\
\text { external communication. The other enterprises } \\
\text { are rarely. }\end{array}$ & $\begin{array}{l}\text { - Technology innovations. } \\
\text { - Systems and process innovation (develop- } \\
\text { ment of ICT applications for process improve- } \\
\text { ment). } \\
\text { - Technology analysis (the consideration of } \\
\text { technological tenders and making recom- } \\
\text { mendations for the activation of new ICT). }\end{array}$ \\
\hline
\end{tabular}

Izvor: Cragg, 2008, 32

Table 3 Key technical factors and appropriate ICT competences

\begin{tabular}{lll}
\hline \multicolumn{1}{c}{ Ključna tehnička praksa } & \multicolumn{1}{c}{ Practice description } & \multicolumn{1}{c}{ Related ICT competencies } \\
\hline $\begin{array}{l}\text { Customization of new ICT } \\
\text { systems }\end{array}$ & $\begin{array}{l}\text { For larger enterprises, it is required that cus- } \\
\text { tomization be implemented as planned, and for } \\
\text { other very rare. }\end{array}$ & $\begin{array}{l}\text { Applications development (the development } \\
\text { and implementation of ICT solutions and satis- } \\
\text { fying business needs). }\end{array}$ \\
\hline & $\begin{array}{l}\text { ICT leader employ ICT specialist with years of } \\
\text { formal ICT training. In other enterprises, using } \\
\text { the technical experts from the region (out- } \\
\text { ICT specialists }\end{array}$ & $\begin{array}{l}\text { ICT staff development (recruitment, training, } \\
\text { and deployment for the enterprise's needs). }\end{array}$ \\
\hline ICT development skills & $\begin{array}{l}\text { In ICT leaders, there is at least one person } \\
\text { engaged in the specific areas of ICT (software, } \\
\text { hardware, network and other). In other enter- } \\
\text { prises, there is no such person. }\end{array}$ & $\begin{array}{l}\text { Apply technology (the most cost-effective } \\
\text { mode to application benefits). }\end{array}$ \\
\hline
\end{tabular}

Source: Cragg, 2008, 33

experience, technical skills as well as behavior and attitudes will be defined in practice. According to this model, the ICT strategy balances business changes with ICT initiators.
According to the previous researches (Prytibok et al, 2008; Chen et al, 2011, Harton et al, 2010; Ngwenyama, \& Morawczynski, 2009; Cragg, 2008; Peppard \& Ward, 2004; Tanriverdi, 2006; Weil \& Ross, 2004), it could be concluded that the level of investments made in ICT, directly and indirectly (through ICT strategy), has an 
influence on the quality of the implementation of ICT solutions. In the listed researches, it was, on average, proven through different case studies and theoretical analyses that, in enterprises in clusters, there is a positive influence between the level of investment in ICT and the quality of the implementation of ICT , with a higher or lower regression coefficient. The basic ground is that investments are meaningful and, when supported by an ICT strategy as an element of a corporate strategy, show a higher level of the quality implementation of ICT solutions as a result.

\section{RESEARCH METHODOLOGY}

The research in this paper was performed in three phases via appropriate methodologies such as:

- The analysis of the reference literature resources for the identification of the key determinants of the quality of the implementation of ICT solutions,

- The development of a questionnaire to be sent to enterprises, the analysis of the validity of the data in the development of appropriate data tables and spreadsheets,

- The usage of the statistical tool box of MATLAB and the analysis of the significance of the model.

The process model of an enterprise is the basis for the analysis of the implementation of an ICT

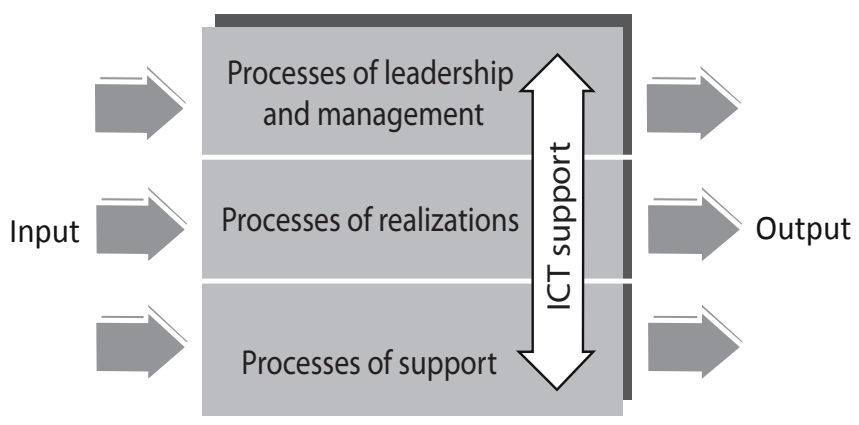

Figure 1 Generic IPO model of an enterprise solution. Enterprises in a cluster communicate with the enterprises inside and outside the cluster using ICT. Using an Input-Process-Output (IPO) analysis in enterprises in a cluster, a generic IPO model of enterprises is developed (Figure 1). According to the IPO model, an enterprise could be presented as a network of processes communicating via ICT resources. In this model, processes are grouped in three generic groups:

- Processes of leadership and management,

- Processes of realizations, and

- Processes of support.

Dominant communication is realized between generic processes in enterprises, ICT-supported in communication. If there is ICT support, it enables external communication by managing inputs and outputs in an enterprise. An enterprise's input and output are separately analyzed for all groups of subprocesses as well as for each process separately. This generic model of the functioning of the enterprise enables the development of a model for the quality of the implementation of ICT. Based on the analyzed reference literature, the following variables were selected from defined generic processes in the IPO model and included in the model:

- Leadership and management processes

$\mathrm{V}_{1}$ - the level of investment in ICT,

$\mathrm{V}_{2}$ - the quality of management,

$\mathrm{V}_{3}$ - the level of the quality of the processes,

$\mathrm{V}_{4}$ - the level of ICT strategies

- Realization processes

$\mathrm{V}_{3}$ - the level of the quality of the processes

- Support processes

$\mathrm{Y}$ - the level of the quality of ICT implementation.

Figure 2 depicts the starting model of the quality of the implementation of ICT. In this model, the variable $Y$ is defined as the aggregate variable, based on data about the level of the quality of information, the quality of ICT functioning and ICT customers' satisfaction. 


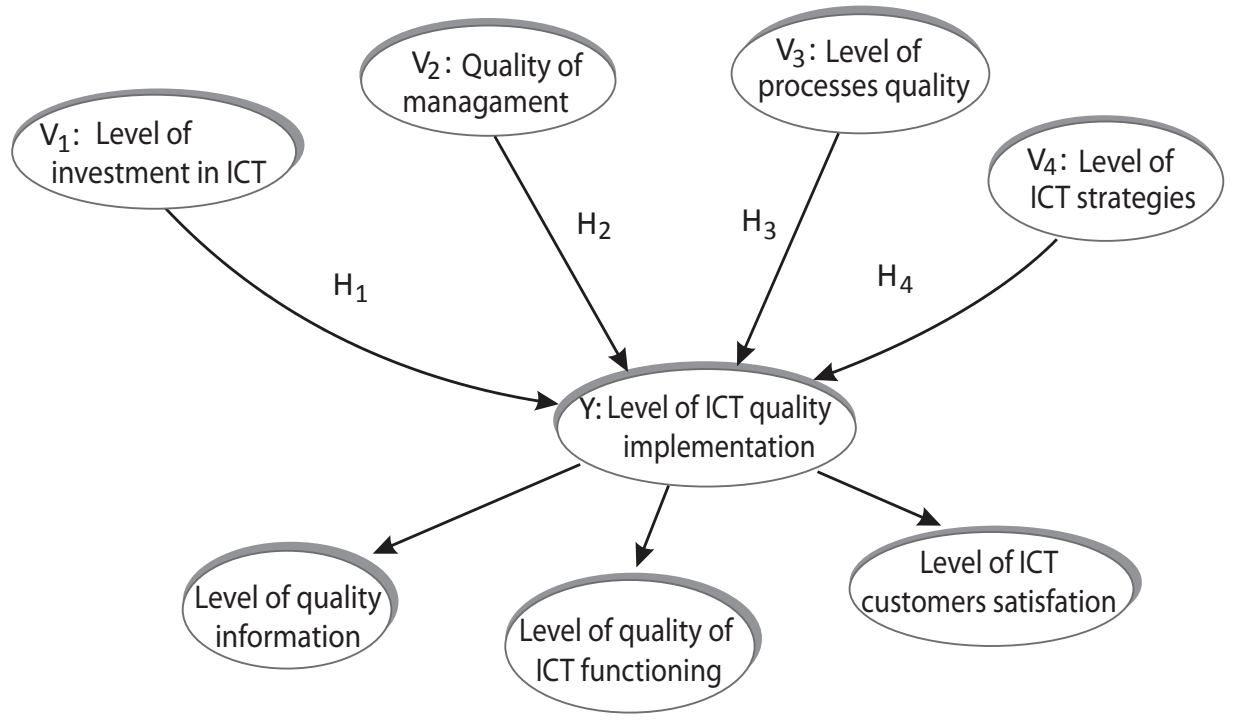

Figure 2 The quality model of the implementation of ICT

Source: Author

The level of investment in ICT $\left(\mathrm{V}_{1}\right)$ is defined based on the share of investment in ICT compared to the total investment in an organization, presented in percentage at the annual level. Using appropriate metrics, it is translated into a mark on the 1-to-10 scale.

The level of the quality of management $\left(\mathrm{V}_{2}\right)$ is evaluated as the quality of management processes, composed from the following sub-processes:

$\mathrm{P}_{0} 1$ - Planning,

$\mathrm{P}_{0} 2$ - Organizing,

$\mathrm{P}_{0} 3$ - Controlling, and

$\mathrm{P}_{0} 4$ - Directing.

The quality of a process $\left(\mathrm{V}_{3}\right)$ is determined based on the metrics for each process separately (marketing, sale, purchasing) and is accounted for at the level of an organization for all processes as a whole.

The ICT strategy $\left(\mathrm{V}_{4}\right)$ is observed as a process, and its level is defined based on the quality of:

- Plans for the fulfillment of the strategic ICT goals,

- Strategy/plans for the improvement of ICT customers' satisfaction,
- Plans for human resources for ICT,

- The allocation of resources for the effective functioning of ICT, and

- Relegations with partners, suppliers and vendors of ICT equipment.

The quality of ICT implementation $(\mathrm{Y})$ could be analyzed as a triad of the following aspects:

- The quality of information, based on the content, availability, accuracy, consistency and availability for usage,

- The quality of ICT functioning, based on reliability, easy usage, accessibility, usefulness and flexibility, and

- ICT customers' satisfaction (internal and external), based on the reliability of the acquired service, the time of a right response, empathy and competitiveness for the received information.

The influence of the level of investments in ICT $\left(\mathrm{V}_{1}\right)$ has been analyzed in many theoretical and applicative researches, especially in (Tonchia \& Tramontano, 2004; Aikens 2011; Prytibok et al, 2008; O'Brien \& Marakas, 2011). Most of these researches refer to medium and large enterprises, with a higher maturity level and 
experience in the implementation of ICT. It was argued that there is a positive relation with changes in the intensities of a number of factors.

According to the previous analysis and the stated model of the quality of ICT implementation (Figure 2), the basic hypothesis of the synergic effect of the determinants of the quality of ICT implementation is set:

$\mathrm{H}_{0}$ : The level of investment in ICT $\left(\mathrm{V}_{1}\right)$, the level of the quality of management $\left(\mathrm{V}_{2}\right)$, the level of processes quality $\left(\mathrm{V}_{3}\right)$ and the level of ICT strategy $\left(\mathrm{V}_{4}\right)$, have a positive effect on the exogenous variable - the level of the quality of ICT implementation (Y).

Beside the basic hypothesis, due to the specificity of the business environment in Serbia, the additional hypotheses were set. These hypotheses should emphasize the significance of each stated determinant on the quality of ICT implementation:

$\mathrm{H}_{1}$ : The level of investment in ICT $\left(\mathrm{V}_{1}\right)$ has a positive impact on the level of the quality of ICT implementation $(\mathrm{Y})$;

$\mathrm{H}_{2}$ : The level of management quality $\left(\mathrm{V}_{2}\right)$ has a positive impact on the level of the quality of ICT implementation (Y);

$\mathrm{H}_{3}$ : The level of processes quality $\left(\mathrm{V}_{3}\right)$ has a positive impact on the level of the quality of ICT implementation $(\mathrm{Y})$;

$\mathrm{H}_{4}$ : The level of the ICT strategy $\left(\mathrm{V}_{4}\right)$ has a positive impact on the level of the quality of ICT implementation $(\mathrm{Y})$.

Hypothesis $\mathrm{H}_{1}$ refers to the level of investments $\left(\mathrm{V}_{1}\right)$ in the quality of ICT implementation $(\mathrm{Y})$, respecting the fact that, in a number of enterprises in RS, there is no defined ICT strategy, especially in the group of small and medium-sized enterprises (Schultheis \& Sumner, 1998; Stefanović, 2005; RZS, 2012), which represent over $90 \%$ of all enterprises.

Hypothesis $\mathrm{H}_{2}$ refers to the influence of management quality on the level of the quality of ICT implementation. Based on the relevant literature (Arsovski et al, 2009) referring to MIS (Management Information Systems
- MIS) and quality management (Aikens, 2011; Evans, 2011; Oukland, 2004), hypothesis $\mathrm{H}_{2}$ refers to the direct influence of the level of management quality $\left(\mathrm{V}_{2}\right)$ on the quality of ICT implementation (Y). The assumption for this relation is a relatively high level of management quality and investment in ICT, which is an exception for the Serbian business environment. The results of the researches should be confirmed in domestic enterprises, where there is a relatively low level of management quality (Arsovski, Arsovski \& Nikezić, 2012) and ICT strategies (Arsovski et al, 2012; Stefanovic et al, 2012).

Hypothesis $\mathrm{H}_{3}$ refers to the influence of the processes quality $\left(\mathrm{V}_{3}\right)$ on the level of the quality of ICT implementation $(Y)$. This hypothesis was researched in enterprises in developed countries and proved in the reference literature (Prytibok et al, 2008; Wagner, 2004; Wieder et al, 2006). Researches in domestic enterprises should prove the value of the regression coefficient in this relation.

Hypothesis $\mathrm{H}_{4}$ refers to the influence of the quality of the ICT strategy $\left(\mathrm{V}_{4}\right)$ on the level of the quality of ICT implementation $(\mathrm{Y})$, which is proved in many researches, in particular in those conducted by foreign authors in the field of ICT (Turban et al, 2006; Laudon K \& Traver, 2008; Prytibok et al, 2008; Wagner, 2004; Cragg, 2002). In the domestic environment, with a relatively low level of variables $V_{3}$ and $V_{4}$, it is necessary that the value of the regression coefficient in this relation should be researched and confirmed.

A questionnaire with the defined variables $V_{1}, V_{2}, V_{3}$, $V_{4}$ and $Y$, information about the clusters, enterprises, and a corresponding person, was sent to the selected enterprises in RS (150). The researched enterprises filled out their questionnaires for the level of variables on the 1-to-10 scale, where 1 is the lowest and 10 - the highest grade. Based on these grades, the database was formed with the tables of the models, clusters, enterprises, variables, questionnaires and statistical software (Figure 3).

Based on the information gathered from 74 questionnaires (with a $49 \%$ response percentage), the created database was updated. 


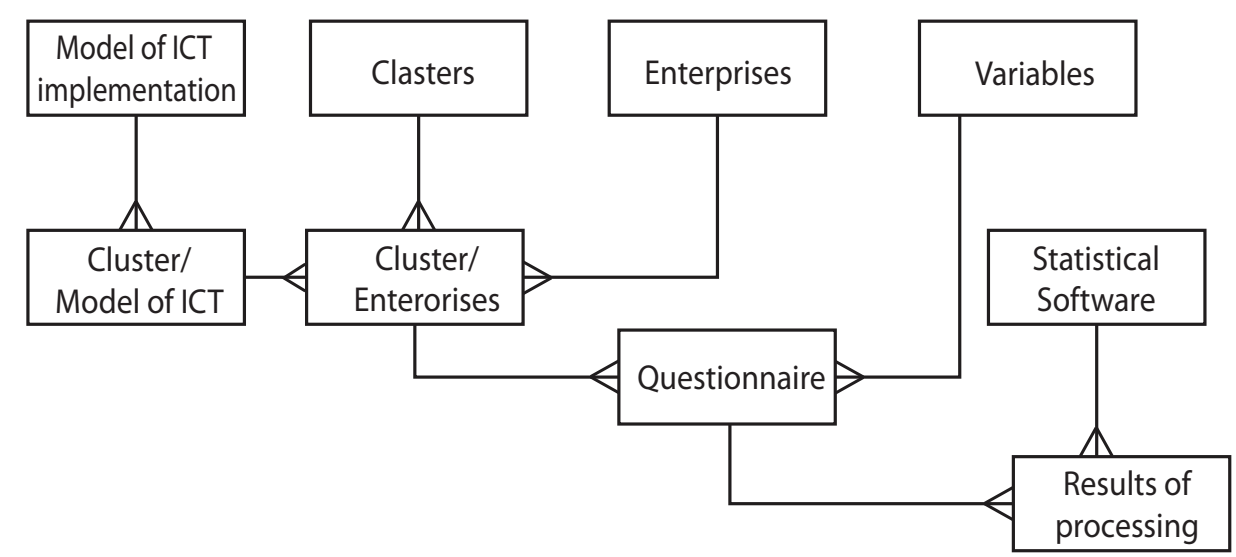

Figure 3 The structure of the "Determinants of the Implementation of ICT" database

Source: Author

\section{RESEARCH RESULTS}

Based on the stated model of the quality of ICT implementation presented in Figure 2 a relation between $\mathrm{Y}$ (the quality of ICT implementation) and the independent variables $\left(V_{1}, V_{2}, V_{3} \quad i V_{4}\right)$ has been defined:

$\mathrm{Y}=\mathrm{a}_{0}+\mathrm{a}_{1} \mathrm{~V}_{1}+\mathrm{a}_{2} \mathrm{~V}_{2}+\mathrm{a}_{3} \mathrm{~V}_{3}+\mathrm{a}_{4} \mathrm{~V}_{4}$

where:

$a_{i}(i=0-4)-$ the constants obtained by the multiple regression procedure

$\mathrm{V}_{1}$ - Level of investment in ICT,

$\mathrm{V}_{2}$ - Level of quality management,
$\mathrm{V}_{3}$ - Level of processes quality,

$\mathrm{V}_{4}$ - Level of ICT strategies.

The defined quality model of ICT implementation has been tested on the sample of 74 enterprises, where the accuracy and reliability of the data were analyzed. Table 4 accounts for the data related to the enterprise size based on the number of employees and the business areas.

The procedure of the statistical analysis was performed in three steps. In the first step, it was analyzed on whether there is any correlation between the variables presented in the model by calculating Pearson's coefficient of correlation. In the second step, the

Table 4 The structure of the enterprises in the researched cluster according to the business areas and the number of employees

\begin{tabular}{l|cccccc}
\hline \multirow{2}{*}{$\begin{array}{c}\text { Business area } \\
\text { Number of employees }\end{array}$} & $\begin{array}{c}\text { Baking Industry } \\
\text { and services }\end{array}$ & $\begin{array}{c}\text { Water production } \\
\text { and liquid beverages }\end{array}$ & $\begin{array}{c}\text { Meat pro- } \\
\text { cessing }\end{array}$ & $\begin{array}{c}\text { Other } \\
\text { services }\end{array}$ & $\begin{array}{c}\text { Related } \\
\text { industry }\end{array}$ & Total \\
\cline { 1 - 5 } $0-9$ & $30 / 25$ & $1 /-$ & - & $10 / 4$ & $3 / 2$ & $44 / 33$ \\
$10-49$ & $2 / 2$ & $1 / 1$ & $1 / 1$ & $5 / 3$ & $3 / 2$ & $12 / 9$ \\
$50-125$ & $1 / 1$ & $2 / 2$ & $2 / 2$ & $3 / 1$ & $3 / 2$ & $11 / 8$ \\
$125-250$ & - & $1 / 1$ & $1 / 1$ & $1 / 1$ & $1 /-$ & $4 / 3$ \\
$>250$ & - & $3 / 2$ & - & - & - & $3 / 2$ \\
Total & $33 / 28$ & $8 / 6$ & $4 / 4$ & $19 / 9$ & $10 / 6$ & $74 / 53$ \\
\hline
\end{tabular}


correlation between each of the independent variables $\left(\mathrm{V}_{1}, \mathrm{~V}_{2}, \mathrm{~V}_{3}\right.$ and $\mathrm{V}$ ) $)$ and the dependent variable $(\mathrm{Y})$ was calculated. In the third step, the multiple regression analysis was used to determine total correlation (as the result of the synergistic effect) among all the independent variables $\left(\mathrm{V}_{1}, \mathrm{~V}_{2}, \mathrm{~V}_{3}\right.$ and $\left.\mathrm{V} 4\right)$ and the dependent variable $(\mathrm{Y})$.

The analysis of the 74 responses gathered from the enterprises showed that there are non-conformities in the 21 enterprises, so the number of the answers was reduced to the responses from the 53 enterprises. The structure of the final sample, according to the business areas and the number of employees, is provided in Table 4, where the first number shows the data collected from the starting sample of the 74 enterprises, and the number after the back slash shows the data connected with the final sample of the 53 enterprises. The database was updated with the checked and validated data. These data were used for the procedure of multiple linear regressions using the MATLAB software application (2):

$Y_{i}=\beta_{0}+\sum \beta_{i j} X_{j}+\varepsilon_{i}$

where:

$\mathrm{Y}_{\mathrm{i}}$ - the dependable (endogen) variable,

$\mathrm{X}_{\mathrm{i}}$ - the repressor (exogenous or independent variable) and

$\varepsilon_{\mathrm{i}}-$ the unidentified random variable (error, noise).

Considering the situation with more variables $(i=3)$, using the Fisher $(F)$ statistics, the relations in the model were defined and the following statements were confirmed:

- There is no linear correlation between the independent variables $V_{1}, V_{2}, V_{3}$ and $V 4$ (the Pearson coefficient of correlation for all the variables, ranging from 0.042619 to 0.198618 , which is smaller than the border value for the sample of the 53 enterprises, which is 0.27 for the significance level of $5 \%$ ).

- There is a significant correlation between all the pairs in the model (the independent variables $\mathrm{Vi}$, $\mathrm{i}=1-4$, and the dependent variable $\mathrm{Y}$ ), expressed by Pearson's coefficients ranging between 0.403503 and 0.439053 , which is higher than the border value of 0.27 for the level of significance of $5 \%$.

The key $\mathrm{H}_{0}$ hypothesis of this research refers to the synergic effect of the variables $\mathrm{V}_{1}, \mathrm{~V}_{2}, \mathrm{~V}_{3}$ and $\mathrm{V} 4$ on $Y$ (the quality of ICT implementation). The statistical analysis resulted in the equation (3) with the total 0.4768 correlation coefficient, which is higher than the highest separate correlation coefficient between $\mathrm{Vi}$ and Y (0.439053):

$$
\begin{aligned}
\mathrm{Y} & =-6,3668+0,3388 * \mathrm{~V}_{1}+0,6759 * \mathrm{~V}_{2}+ \\
& +0,4461 * \mathrm{~V}_{3}+0,3854 * \mathrm{~V}_{4}+\mathrm{e} \\
\mathrm{R}^{2} & =0,4768, \mathrm{e}=2,4071
\end{aligned}
$$

The relation (3) is the result of using the equation (2), which refers to the multiple linear regression, a significant statistical significance, because the variables $\mathrm{V}_{1}, \mathrm{~V}_{2}, \mathrm{~V}_{3}$ and $\mathrm{V} 4$ with the correlation coefficient of $\mathrm{R} 2=0.4768$ affect the variable $\mathrm{Y}$. The variable $\mathrm{V}_{2}$ (the quality of management), with the factor 0.6759 , has the highest influence, and is followed by the variable $V_{3}$ (the level of processes quality) with the factor 0.4461 , and finally, although of the significantly lower influence of the variables $V_{1}$ (investments in ICT) and V4 (the level of the ICT strategy) on Y (the quality of ICT implementation).

Figures 4, 5, 6 and 7 depict the dependence of the determinants of the implementation of ICT on the quality of ICT implementation obtained by a single linear regression procedure.

The analysis of the relation presented in Figure 4 results in the conclusion that hypothesis $\mathrm{H}_{1}$ is confirmed, but with a relatively high value of Pearson's correlation coefficient $\mathrm{R}=0.439053$.

Hypothesis $\mathrm{H}_{2}$ is confirmed because the value of Pearson's correlation coefficient is $\mathrm{R}=0.403503$, which is significantly higher than the border value of 0.27 for the significance level of 5\% (Figure 5).

The influence of $\mathrm{V}_{3}$ on $\mathrm{Y}$ (hypothesis $\mathrm{H}_{3}$ ) presented in Figure 6 was confirmed in the analyzed sample because the average value of Pearson's correlation coefficient is $\mathrm{R}=0.411596$. 


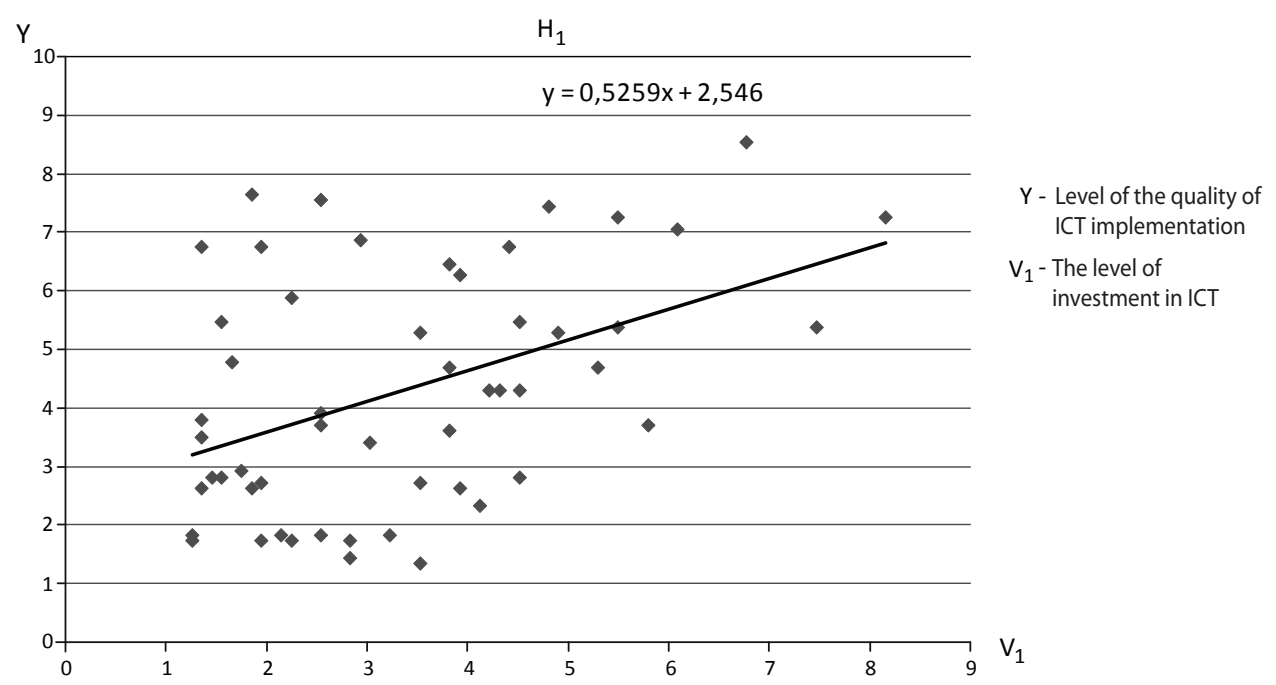

Figure 4 The correlation of the level of the quality of ICT implementation $(\mathrm{Y})$ and the level of investment in ICT $\left(\mathrm{V}_{4}\right)$ Source: Author

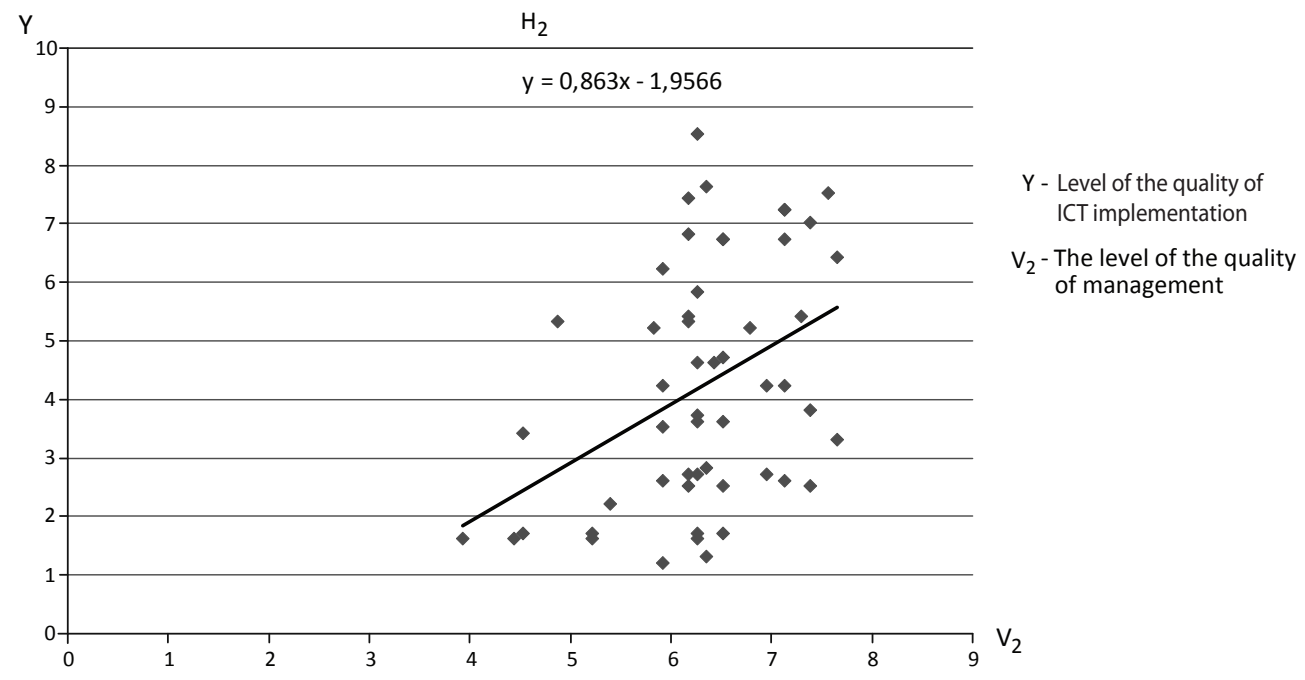

Figure 5 The correlation of the level of the quality of ICT implementation $(\mathrm{Y})$ and the quality of management $\left(\mathrm{V}_{2}\right)$

Source: Author

The analysis of the influence of V4 on $\mathrm{Y}$ (hypothesis $\mathrm{H}_{4}$ ) presented in Figure 7 shows that the value of Pearson's correlation coefficient is $\mathrm{R}=0.403932$, which confirms hypothesis $\mathrm{H}_{4}$.

So, the partial hypothesis $\mathrm{H}_{1}(\mathrm{R}=0.439053), \mathrm{H}_{2}(\mathrm{R}=$ $0.403503), \mathrm{H}_{3}(\mathrm{R}=0.411596), \mathrm{H}_{4}(\mathrm{R}=0.403932)$, as well as the main hypothesis $\mathrm{H}_{0}$, are confirmed, which refers to the total influence of the variables $\mathrm{V}_{1}, \mathrm{~V}_{2}, \mathrm{~V}_{3}$ and $\mathrm{V} 4$ on the variable $Y(R=0.4768)$ and the achieved synergic effect of the variables in the model.

The relatively high coefficient of variation in the variables $\mathrm{V}_{1}$ and $\mathrm{Y}$ is indicative of the fact that this 


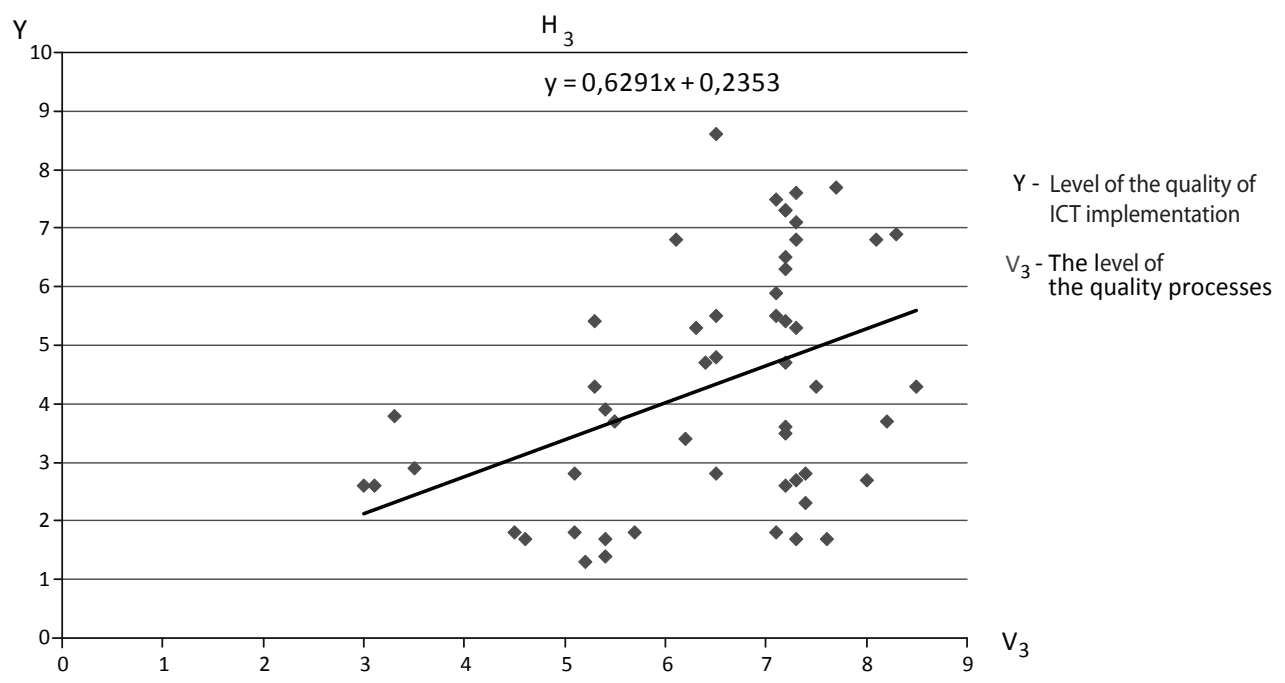

Figure 6 The correlation of the level of quality of ICT implementation $(\mathrm{Y})$ and the level of processes quality $\left(\mathrm{V}_{3}\right)$ Source: Author

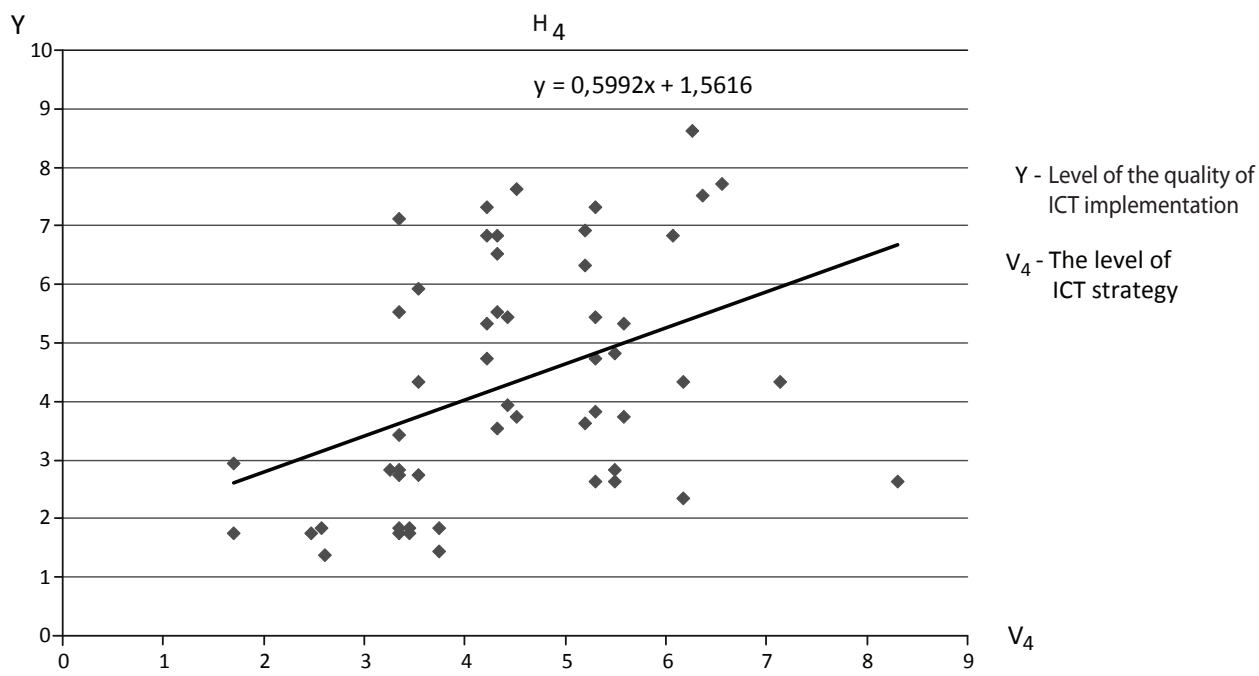

Figure 7 The correlation of the level of the quality of ICT implementation (Y) and the level of the ICT strategy (V4) Source: Author

variable - in which the proportion of a very high statistical noise reduces the accuracy of the prediction of the initial model. This might be expected because the enterprises in the cluster have different levels of ICT, which requires different levels of investment in ICT.
The analysis of the impact of the variables $V_{2}$ on $Y$, as shown in Figure 5, lead us to a conclusion that there is a positive impact $(R=0.403503)$, which can be increased by introducing additional variables (in this case, the variable level of the knowledge management of ICT). 
Table 5 accounts for the mean values and the standard deviations for all the variables in the model $\left(\mathrm{V}_{1}, \mathrm{~V}_{2}\right.$, $\mathrm{V}_{3}, \mathrm{~V} 4$, and $\mathrm{Y}$ ) necessary for the evaluation of the coefficient of variation.

Table 5 The mean values and the standard deviations of the variables in the model

\begin{tabular}{|c|c|c|c|c|c|}
\hline $\begin{array}{l}\text { Variables } \\
\text { Results }\end{array}$ & $V_{1}$ & $V_{2}$ & $V_{3}$ & $V_{4}$ & Y \\
\hline Mean values & 3.328 & 7.245 & 6.454 & 4.564 & 4.296 \\
\hline $\begin{array}{l}\text { Standard } \\
\text { deviations }\end{array}$ & 1.720 & 0,963 & 1.348 & 1.389 & 2.060 \\
\hline
\end{tabular}

Source: Author

Based on the analysis of the results of the research, the starting model of ICT implementation was confirmed on the selected sample hypothesis $\mathrm{H}_{1}, \mathrm{H}_{2}, \mathrm{H}_{3}, \mathrm{H}_{4}$ as well as on the main hypothesis $\mathrm{H}_{0}$ regarding the influence of the variables $\mathrm{V}_{1}, \mathrm{~V}_{2}, \mathrm{~V}_{3}$ and $\mathrm{V} 4$ on the variable $Y$ (the level of ICT implementation). Based on the equation (3), it could be concluded that $V_{2}$ (the quality of management with the factor 0.6759) and then the variable $V_{3}$ (the level of processes quality with the factor 0.4461) had the biggest influence on the variable Y. Given the limited financial resources of the clusters of enterprises in RS, currently a significant increase in the quality of the implementation of ICT $(\mathrm{Y})$ can be expected primarily by increasing the variables $V_{2}$ and $\mathrm{V}_{3}$, without a significant investment. In the case of the increasing variables $\mathrm{V}_{2}$ by $20 \%$ and $\mathrm{V}_{3}$ by $10 \%$, the total value of the variable $Y$ would be increased by $29.6 \%$.

Considering the fact that, according to (Pritybok et al, 2008, 149), the influence of $Y$ on an enterprise's performance is 0.79 , in the clusters of enterprises in RS the net benefits of ICT, without making a significant investment, can be expected to increase to $20 \%$.

\section{CONCLUSION}

The problem of ICT implementation was recognized as early as at the beginning of the ICT era. In many different fields such as technology, human resources, education and management, the economy was an area of research for a solution to this problem. A number of studies have presented the key determinants and their level of influence on the different aspects of the implementation of ICT in enterprises. Two groups of problems were analyzed: the influence of ICT on the performances of enterprises and the influence of internal and external enablers on the behavior of the implementation of ICT in enterprises. This paper was directed towards a solution to the second group of problems, especially in small and medium-sized enterprises connected with weak links inside a cluster.

Starting from the theory and practice of organizing clusters, the author analyzed 53 organizations, connected in a cluster with weak links, where small and medium-sized enterprises were dominant. The representation of this sample approximately corresponds to the structure of the Serbian industry. Based on the developed model of ICT implementation, a questionnaire was designed with an appropriate structure of questions referring to the values of the selected variables for a specific enterprise. Based on the reference literature, the four determinants were selected as variables: (1) the level of investments in ICT, (2) the level of management quality, (3) the level of processes quality and (4) the level of ICT strategies. Directly or indirectly, these variables have an influence on the dependable variable (the level of the quality of ICT implementation). Because small enterprises were predominant in the analyzed sample, the presented grade for each variable in a enterprise, made by a manager/owner, resulted in the higher dissipation of the values in the sample. Comparing the gathered values with the reference papers from this field, the coefficient of the variation is $15-40 \%$, which is above the average values, which is the result of the differences in the size of organizations, the industry sector and in predominantly local competition.

This paper mainly contributed to the calculation of the influence of the variables: investment in ICT $\left(\mathrm{V}_{1}\right.$ - the impact factor 0.3388$)$, the quality of management $\left(\mathrm{V}_{2}-\right.$ the impact factor 0.6759$)$ and the quality of processes $\left(\mathrm{V}_{3}\right.$ - the impact factor 0.4461$)$ and the ICT strategy (V4 - the impact factor 0.3854). This relation (3) could be used for the simulation of the effects of improvement 
on the behavior of the implementation of ICT in practice. Considering the relatively low investments in ICT, with negligible investments, much better performances for the implementation of ICT in practice could be expected to result in a further improvement in the performances of enterprise. This approach could be used for an improvement of ICT strategies, which exist at a basic level in most enterprises, and for them to make an improvement, enterprises should engage external experts. The third one, according to the impact, is the variable referring to the quality of the process in an enterprise. An improvement of this variable could be achieved by introducing management systems (ISO 9001, ISO 20000, ISO 27000 etc.), specifications and the sectoral standards (HACCP, Information architecture, eTOM, etc.) as well as the principles of good practice. No significant investments are needed for an improvement of the value of this variable.

The constraints in this paper refer to the size of the sample, the structure of the cluster as well as to the low level of the implementation of modern ICT in enterprises in the cluster. The size of the cluster is limited by the existing number of enterprises belonging to specific clusters in RS; however, the sample used in this paper (53 enterprises) could be expanded to 90 enterprises in further investigations. In such an increased sample, enterprises could be grouped by the size and the business area. The results of a future research using a larger sample could be expected to result in a higher correlation coefficient and a better prediction of the behavior of the enterprises in the cluster.

The achieved results of the research and the overcoming of these constraints will be a good basis for a new research in the following areas: (1) the introduction of the control variables, such as the size of the enterprise, its business characteristics, the maturity of enterprise, competitiveness, (2) the definition of an extended model of ICT implementation in practice on the basis of additional system indicators, (3) the development of the simulation software for the evaluation of the influence of ICT on the performances of an enterprise, and (4) the comparison of the quality level of ICT implementation in different clusters in the Republic of Serbia.

\section{ACKNOWLEDGMENTS}

This paper is a part of the research Project (No. 44010), which is funded by the Ministry of Science of the Republic of Serbia.

\section{REFERENCES}

Aikens, C. H. (2011). Quality Inspired Management: The Key to Sustainability. USA: Prentice Hall, Boston.

Albright, S. C., Zappe, C., \& Winston, W. (2011). Data Analysis, Organization and Simulation Modeling. Canada: South Western Cengage Learning.

Arsovski, Z., Arsovski, S., Mirović, Z., \& Stefanović, M. (2009). Simulation of quality goals: A missing link between corporate strategy and business process management. International Journal for Quality Research, 4(1), 449-459.

Arsovski, Z., Arsovski, S., Ranković, V., Kalinić, Z., Rejman Petrović, D., \& Milanović, I. (2012). Quality Concept in Enterprise Management. In A. Malina, R. Oczkowska, T. Rojek, (Eds.), Knowledge, Economy Society - Dilemmas of the Contemporary Management (pp. 501-516). Cracow: Cracow University of Economics.

Arsovski, Z., Arsovski, S., \& Nikezić, S. (2012). Developement of quality management in enterprises of Serbia. Journal of Technics Tehnologies Education Management, 7(2), 944-949.

Berghmans, P., \& Roy, K. (2011). Information security risks in enabling e-goverment: The impact of IT Vendors. Information System Management, 28(4), 284-293. DOI: $10,1080 / 10580530,2010,514212$

Becker, J. (2003). Process Management. Berlin: Spriger.

Brah, A. S., \& Lim, H. Y. (2006). The effects of technology and TQM on the performance of logistics companies. International Journal of Physical Distribution \& Logistics Management, 36(3), 192-209. DOI: 10,1108/09600030610661796

Casadesus-Masanell, R., \& Ricart, J. (2009). From Strategy to Business Models and Onto Tactics. USA: Harward Business School.

Chen, W., Elnaghi, M., \& Hatzakis, T. (2011). Investigating knowledge management factors affecting Chinese ICT firm performance: An integrated KM framework. Information Systems Management, 28(1), 19-29. DOI: $10,1080 / 10580530,2011.536107$ 
Cragg, P. (2002). Benchmarking information technology practices in small firms. European Journal of Information Systems, 11(4), 267-282. DOI: 10,1057/palgrave.ejis.3000430

Cragg, P. (2008). Identifying key information systems competencies in small firms. Total Quality Management \& Business Excellence, 19(1-2), 29-35. DOI: $10,1080 / 14783360701601926$

Cragg, P., Caldeira, M., \& Ward, J. (2006). Information systems competencies in small manufacturing firms. Working paper, AFIS, NZ: University of Canterbury.

Evans, J. (2011). Quality, Management, Organization and Strategy. USA: South-Western Cengage Learning.

Franke, H. J., \& Pfeifer, T. (1998). Qualitaets-Information Systeme. Wien: Carl Hanser.

Gadatsch, A. (2005). Grundkurs Geschäftsprozess Management. Berlin: Vieweg.

Gordon, I. R., \& McCan, P. (2000). Industrial clusters: Complexes, agglomeration and/or social networks? Urban Studies, 3, 513-532.

Gordon, I. R., \& McCan, P. (2005). Innovation, agglomeration and regional development. Journal of Economic Geography, 5(5), 523-543.

Harton, E., Li, X., Na, K. S., \& Simpson, J. (2010). The role of quality of shared information in interorganizational systems use. International Journal of Information Management, 30(5), 399-407. DOI: 10,1016/j.ijinfomgt.2010,02.007

Iammarino, S., McCann, P. (2006). The structure and evolution of industrial clusters: Transactions, Technology and Knowledge Spillovers. Research Policy, 35(7), 1018-1036. DOI: 10,1016/j.respol.2006.05.004

Laudon, K., \& Laudon, J. (2012). Management Information Systems: Managing the Digital Firm. Twelth Edition. Pearson.

Laudon, K., \& Traver, C. G. (2008). E-Commerce: Business, Technology, Society. Pearson/Prentice Hall.

Leidner, D., Lo, J., \& Preston, D. (2011). An empirical investigation of the relationship of IS strategy with firm performance. Journal of Strategy Information Systems, 20(4), 419-437. DOI: 10,1016/j.jsis.2011.09.001

Martin, E. et all. (2011). Management Information Systems. Prentice Hall.

Mc Fadzean, E., Ezingeard, J., \& Birschall, D. (2011). Information assurance and corporative strategy: A Delphi study of choices, challenges, and developments for the future. Information Systems Management, 28(2), 102-128. DOI: 10,1080/10580530,2011.562127
Mirchandani, D., \& Lederer, A. (2012). Less is more: Information systems planning in an uncertain environment. Information Systems Management, 29(1), 13-25. DOI: $10,1080 / 10580530,2012.634293$

Morosini, P. (2004). Industrial clusters, knowledge integration and performance. World Development, 32(2). 305-326. DOI: 10,1016/j.worlddev.2002.12.001

Ngwenyama, O., \& Morawczynski, O. (2009). Factor affecting ICT expansion in emerging economies: An analysis of ICT infrastructure expansion in five Latin American countries. Information Technology for Development, 15(4), 237-258. DOI: 10,1002/itdj.20128

O’Brien, J., \& Marakas, G. (2011). Management Information Systems. New York: McGraw Hill, IRWIN.

Oukland, J. (2004). Oukland on Quality Management. Burlington, MA: Elsevier.

Peppard, J., \& Ward, J. (2004). Beyond strategic information systems: Towards an IS capability. Journal of Strategic Information Systems, 13(2), 167-194. DOI: 10,1016/j. jsis.2004.02.002

Prytibok, V., Zhang, X., \& Ryan, S. (2008). Evaluating leadership, IT quality and net benefits in an e-government environment. Information and Management, 45(3), 143-152. DOI: 10,1016/j.im.2007.12.004

Ragovsky, A., Licker, P., \& Gafen, D. (2012). Organizational IT maturity (OITM): A measure of organizational readiness and effectiveness to obtain value form its information technology. Information Systems Management, 29(2), 148-160. DOI: 10,1080/10580530,2012.662104

Republički zavod za statistiku (2012). Statistički Godišnjak Republike Srbije - Upotreba informaciono-komunikacionih tehnologija, 2012. datum preuzimanja: 10,08.2013, http:// webrzs.stat.gov.rs/WebSite/repository/documents/ 00/00/82/35/17_Informacione_tehnologije.pdf,.

Rosenfeld, S. A. (2002). Creating Smart Systems: A Guide to Cluster Strategies in Less Favoured Regions. European Union Regional Innovation Strategies.

Roztocki, N., \& Weistroffer, H. R. (2011). Information technology success factors and models in developing and emerging economies. Information Technology for Development, 17(3), 163-167. DOI: 10,1080/02681102.2011.568220

Sanders, N., \& Premus, R. (2005). Modeling the relationship between firm IT capability, collaboration and performance. Journal of Business Logistics, 26(1), 1-23. DOI: 10,1002/j.21581592.2005.tb00192.x

Scheer, A. W. (1999). ARIS - Business Process Framework. Berlin: Springer. 
Stefanović, M. (2005). Renženjering informacionih sistema u Internet okruženju. Neobjavljena doktorska disertacija, Mašinski fakultet Univerzteta u Kragujevcu, Kragujevac, Republika Srbija.

Stefanović, M., Arsovski, S., Arsovski, Z., Aleksic, A., Nestic, S., Rajkovic, D., \& Punosevac, Z. (2012). Integration of virtual an networked organization using server oriented informations. Virtual and Networked Organizations, Emergent Technologies and Tools, Communications in Computer and Information Sciences, 248, 165-175. DOI: 10,1007/978-3-64231800-9_18

Tanriverdi H. (2006). Performance effects of information technology synergies in multibusiness firms. MIS Quarterly, 30(1), 57-77.

Tonchia, S., \& Tramontano, A. (2004). Process Management for the Extended Enterprises: Organizational and ICT Networks. Berlin: Springer, Heidelberg.
Themistocleous, M., Soja, P., \& Rupino da Cunha, P. (2011). The Same, but Different: Enterprise Systems Adoption Lifecycles in Transition Economies. Informaton Systems Management, 28, 223-238. DOI; 10,1080/10580530,2011.585585

Turban, E., Leidner, D., McLaen, E., \& Wetherbe, J. (2006). Information Technology for Management: Transforming Organizations in the Digital Economy. John Willy \& Sons.

Wagner, C. (2004). Enterprise strategy management systems: current and next generation. Journal of Strategic Information Systems, 13(2), 105-128. DOI: 10,1016/j.jsis.2004.02.005

Weill, P., \& Ross, J. W. (2004). IT Governance: How Top Performers Manage IT Decision Rights for Superior Results. Boston: Hardvard Business School Press.

Wieder, B., Booth, P., Matolcsy, Z. P., \& Osimitz, M. L., (2006). The impact of ERP Systems on firms and business process performance, Journal of Enterprise Information Management, $19(1 / 2), 13-29$.

Zora Arsovski is a professor at the Faculty of Economics, University of Kragujevac. Her scientific field is Statistics and Informatics (teaching the courses in Information Technologies, Information Systems, Management IS and Strategic Planning of IS). She is the author and co-author of nine university books and scientific monographs, with more than 230 papers published in international and national scientific journals and at conferences. She is a member of the Editorial Board in international journals referred to on the SCI/SSCI and the List of the Ministry of Science of the Republic of Serbia and a member of the Scientific Board for international scientific conferences. 


\title{
DETERMINANTE PRIMENE INFORMACIONO- KOMUNIKACIONIH TEHNOLOGIJA U KLASTERIMA PREDUZEĆA
}

\author{
Zora Arsovski* \\ Ekonomski fakultet Univerziteta u Kragujevcu
}

Primena informaciono-komunikacionih tehnologija (Information Communication Technologies - ICT) $\mathrm{u}$ preduzećima, koja su organizovana u okviru klastera, ima svoje specifičnosti, u zavisnosti od nivoa vrste relacija između preduzeća u klasteru. Svrha istraživanja u ovom radu je utvrđivanje determinanti kvaliteta primene ICT u klasterima preduzeća, iz čega je proistekao cilj istraživanja: definisanje i provera modela kvaliteta primene ICT u klasterima preduzeća. Na osnovu teorijskih istraživanja klastera, razvijen je model kvaliteta primene ICT i testirani uticaji determinanti primene ICT, koje se odnose na nivo ulaganja u ICT, kvalitet menadžmenta, kvalitet procesa i nivo primene ICT strategije na nivo kvaliteta primene ICT, čime je potvrđena signifikantnost postavljenih hipoteza. Rezultati istraživanja ukazuju da se sa visokom pouzdanošću može predvideti nivo kvaliteta primene ICT u klasterima, a time i uticaj na performanse preduzeća i klastera u celini.

Ključne reči: informaciono-komunikacione tehnologije, klaster preduzeća, determinante, kvalitet

JEL Classification: M15, L15, P13, R19

\section{UVOD}

U uslovima globalizacije evidentan je rapidan razvoj i primena ICT u svim značajnijim segmentima funkcionisanja društva, zbog čega se u literaturi i praksi koriste izrazi digitalna ekonomija, e-ekonomija i informaciono društvo. Prema E. Turban i ostali (2006, 34), ciljevi primene ICT mogu se posmatrati sa strateškog, taktičkog i operativnog aspekta u oblastima:

\footnotetext{
* Korespondencija: Z. Arsovski, Ekonomski fakultet Univerziteta u Kragujevcu, Đ. Pucara 3, 34000 Kragujevac, Srbija; e-mail: zora@kg.ac.rs
}

- poslovnog udruživanja (lanci snabdevanja, klasteri, mreže, virtuelna preduzeća),

- elektronskog poslovanja (e-business),

- menadžmenta poslovnim procesima (Business Process Management - BPM),

- reinženjeringa poslovnih procesa (Business Process Reengineering - BPR), i

- stalnog poboljšanja kvaliteta, produktivnosti, agilnosti, fleksibilnosti i drugih poslovnih pokazatelja u preduzećima i različitim tipovima poslovnih udruživanja. 
Analize primene ICT resursa $\mathrm{u}$ kompanijama $\mathrm{u}$ USA ukazuju na to da kompanije, na godišnjem nivou, u proseku ulažu u ICT više od 50\% ukupnih investicija i oko 4,2\% godišnjih prihoda (Weil \& Ross, 2004). Zbog toga je menadžment u kompanijama pod stalnim pritiskom da smanji troškove i poveća vrednost ICT resursa u kompaniji, koji su, pre svega, u funkciji poboljšanja performansi sistema, povećanja nivoa kvaliteta usluga/proizvoda, internih i eksternih komunikacija, unapređenja odnosa sa kupcima i dobavljačima.

Klasteri predstavljaju oblik organizovanja različitih preduzeća na određenoj teritoriji, sa specijalizovanim dobavljačima, isporučiocima usluga, preduzećima i institucijama koje ih prate. Prednosti organizovanja preduzeća u okviru klastera su brojne:

- povećan nivo znanja, ostvaren kooperacijom i učenjem između članica klastera,

- izgradnja komplementarnih znanja i veština radi povećanja konkurentnosti klastera,

- ostvariva ekonomija obima,

- jačanje društvenih i drugih neformalnih veza,

- unapređenje tokova informacija između članica klastera,

- ubrzani razvoj novih proizvoda,

- unapređenje prateće infrastrukture i dr.

U ovom radu realizovana su istraživanja usmerena na primenu ICT na nivou preduzeća koja su organizovana u okviru klastera, gde su evidentirani problemi komunikacije i odlučivanja između preduzeća u klasteru. S druge strane, vrednost umreženih preduzeća raste sa brojem njenih korisnika, čime se povećava i broj komunikacija koje utiču na kvalitet odluka korisnika mreže, performanse mreže, odnosno, klastera u celini.

Svrha ovog rada je da utvrdi determinante kvaliteta primene ICT $\mathrm{u}$ preduzećima koja su organizovana $\mathrm{u}$ okviru klastera. Organizacija klastera postaje sve više zastupljena, posebno kod malih i srednjih preduzeća, gde se kooperacija zasniva na dominantnoj primeni ICT. Pri tome, kvalitet primene ICT rešenja značajno utiče i na poslovne performanse preduzeća.
U cilju utvrđivanja kvaliteta primene ICT u klasterima analiziran je klaster sa složenom strukturom, visokim stepenom geografske razudjenosti preduzeća $u$ klasteru, različitih veličina i starosti koja funkcionišu $\mathrm{u}$ različitim privrednim granama (prehrambena industrija, turizam, usluge, ostale industrije u ovoj kategoriji), sa implementiranim različitim ICT rešenjima i nivoom implementacije ICT. Za izabrani klaster analizirane su determinante kvaliteta ICT rešenja, identifikovane kroz postupak istraživanja referentnih literaturnih izvora. U okviru analize identifikovane $\mathrm{su}$, sledeće ključne determinante kvaliteta primene ICT rešenja: (1) nivo ulaganja u ICT, (2) kvalitet menadžmenta, (3) nivo kvaliteta procesa i (4) nivo kvaliteta ICT strategije.

Istraživanje primene ICT u preduzećima obuhvata teorijska i empirijska istraživanja uz primenu metoda i koncepata sistemskog pristupa, teorije ograničenja, upravljanja prema ciljevima, kvaliteta, modeliranja i primene ICT, teorije organizacije i teorije klastera. Aplikativna istraživanja realizovana su primenom metoda i alata za konceptualni dizajn modela, dizajn i analizu upitnika i primenu statističkih metoda podržanih sa ICT.

Rezultati istraživanja su teorijskog i empirijskog karaktera. Kao rezultat teorijskog istraživanja prikazan je model kvaliteta primene ICT rešenja u klasteru. Empirijski rezultat istraživanja je iskazan utvrđenim nivoom uticaja determinanti (promenljivih $\mathrm{u}$ ovom modelu), na kvalitet primene ICT rešenja i prosečnim nivoom determinanti kvaliteta primene ICT.

Praktične implikacije sprovedenih istraživanja za izabrani uzorak klastera ili druge klastere su: (1) utvrđivanje nivoa determinanti primene ICT u Republici Srbiji (RS), (2) utvrđivanje uticaja promenljivih u modelu na kvalitet ICT rešenja i (3) proširenje modela identifikovanjem mogućnosti uključivanja dodatnih varijabli.

$\mathrm{Na}$ osnovu rezultata teorijskih istraživanja, čiji je rezultat razvijen model kvaliteta primene ICT, kao i prikupljenih podataka iz preduzeća u izabranom klasteru, izvršena je statistička obrada i potvrđena signifikantnost postavljenih hipoteza. Posebno izraženu signifikantnost ima ključna hipoteza kojom se izražava sinergijski efekat promenljivih u modelu 
na kvalitet primene ICT rešenja, što ukazuje na to da se sa visokom pouzdanošću može predvideti nivo kvaliteta primene ICT, a time i uticaj primene ICT na performanse preduzeća u klasteru. Takođe, potvrđene su i hipoteze o pojedinačnim uticajima promenljivih na kvalitet primene ICT rešenja.

Rad je strukturiran u pet delova. Nakon uvodnog dela, $\mathrm{u}$ drugom delu dat je pregled literature, relevantne za utvrđivanje ključnih determinanti kvaliteta primene ICT rešenja. U trećem delu je prikazan postupak definisanja i razvoja modela kvaliteta primene ICT rešenja i objašnjene osnove za utvrđivanje pomoćnih (radnih) hipoteza. U četvrtom delu je data struktura uzorka, kao i način statističke obrade rezultata istraživanja. Takođe, u okviru ovog segmenta prezentirane su relacije $\mathrm{u}$ razvijenom modelu, kao i njihova grafička prezentacija koja ukazuje na signifikantnost relacija u modelu. Na kraju rada dati su zaključci, koji ukazuju na validnost postavljenih hipoteza i pravce budućih istraživanja.

\section{PREGLED PRETHODNIH ISTRAŽIVANJA}

Kvalitet primene ICT rešenja zasniva se na sinergijskom efektu kvaliteta informacija baziranih na implementiranim ICT rešenjima (Laudon \& Laudon, 2012; Cragg, 2008; Ngwenyama, \& Morawczynski, 2009; Tanriverdi, 2006), kvalitetu funkcionisanja ICT (Martin et al, 2011; Cragg, 2002) i zadovoljstvu internih i eksternih korisnika ICT (Chen et al, 2011; Cragg et al, 2006; Franke \& Preifer, 1998). Za validnu identifikaciju determinanti kvaliteta primene ICT korišćena je referentna literatura $\mathrm{u}$ oblasti modeliranja procesa (Albright et al, 2011; Casadeus-Masanell \& Ricart, 2009; Gadatch, 2005; Sanders \& Premus, 2005; Becker, 2003; Scheer, 1999), ICT (Tonchia \& Tramontano, 2004; Prytibok et al, 2008), kvaliteta (Harton et al, 2010; Oukland, 2004; Gadatsch, 2005; Evans, 2011) i klastera (Leidner et al, 2011; Iammarino \& McCann, 2006; Gordon \& McCan, 2000; Gordon \& McCan, 2005).

Problem istraživanja ovog rada je interdisciplinaran i multidisciplinaran. U referentnoj literaturi u ovoj oblasti uglavnom dominiraju radovi koji se odnose na lance snabdevanja i e-upravu (e-government). U radu autora: V. Prytibok, X. Zhank i S. Ryan (2008), kvalitet ICT-a je analiziran u e-upravi, gde je liderstvo posmatrano kao determinanta, a neto korist kao funkcija cilja. Pri tome je dokazana hipoteza da kvalitet ICT pozitivno utiče na neto korist na uzorku jedne e-uprave i 339 obrađenih anketnih upitnika.

U radu A. S. Brah-a i H. Y. Lim-a (2006) ukazano je da je ICT povezan sa kvalitetom. Autori su ukupne poslovne performanse podelili u tri grupe: operativne performanse (kao što su troškovi, vreme ciklusa, i dr.), performanse kvaliteta i tehnološke performanse u okviru kojih su i performanse ICT. Pri tome su utvrđeni relativno visoki nivoi uticaja ICT na strateško planiranje $(0,715)$ i usmerenosti na kupca $(0,636)$.

Rizik sigurnosti informacija u e-upravi (Berghmans \& Roy, 2011) je izuzetno značajan. Zbog toga se u primeni ICT mora uvažavati i ovaj aspekt, koji je uključen kroz rizike na strategijskom i taktičkom nivou, dok su rizici primene ICT iskazani kroz kvalitet informacija i kvalitet funkcionisanja ICT. Kod klastera ovi rizici su značajno niži od rizika primene ICT u e-upravi, pa se, kao takvi, u prvom približenju mogu isključiti iz analize.

Druga, vrlo važna grupa problema odnosi se na neizvesnost okruženja. D. Mirchandani i A. Lederer (2012) analizirali su planiranje informacionih sistema (Information Systems - IS) u uslovima neizvesnosti okruženja. Doprinos IS je izražen kroz usklađivanje ICT sa poslovnim potrebama i rizicima i ostvarivanje rasta konkurentnosti primenom ICT.

Kod članica klastera primenjene su različite ICT, sa različitim nivoima zrelosti. A. Ragovsky, P. Licker i D. Gafen (2012) analizirali su ovaj problem sa aspekta uticaja ICT na organizacionu efektivnost i dobijanja nove vrednosti primenom ICT. Pri tome su utvrdili pet nivoa zrelosti i za svaki nivo definisali karakteristike ICT, koje utiču na članice i klijente, odnosno, organizacije (preduzeća) koje su članice klastera.

Za svaku članicu klastera, i klaster u celini, značajan aspekt funkcionisanja je obezbeđenje informacija $\mathrm{i}$ njihovo uključivanje $u$ poslovnu strategiju. $U$ radu autora: E. Mc Fadzean, J. Ezingeard i D. Birschall (2011), analizirano je usklađivanje obezbeđenja informacija i poslovne strategije. Definisan je model obezbeđenja informacija za poslovne strategije i utvrđene su opcije 
za unapređenje usklađivanja informacija sa poslovnom strategijom.

U radu autora N. Chen, M. Elnaghi i T. Harzakis (2011), analizirani su faktori menadžmenta znanjem u Kini, koji utiču na performanse ICT organizacija. U navedenom modelu, jedna od varijabli $\left(\mathrm{V}_{6}\right)$ je ICT, koja značajno utiče na performanse organizacije (faktor uticaja 0,787).

P. Morosini (2004) je identifikovao pet ključnih aspekata, koji su potrebni za ostvarivanje zajedničke vrednosti:

- liderstvo na nivou preduzeća i klastera,

- zajednički elementi (kao što su ponašanje, jezik, kultura, talenti, specijalizacije, razumevanje poslovanja, merenje konkurentnih performansi),

- komunikacioni rituali (događaji, interakcije),

- povezanost znanja, i

- profesionalna rotacija u preduzećima klastera.

U modelu P. Morosini-a (2004), posebno je istaknuta uloga liderstva i zajedničkih elemenata u pogledu utvrđivanja lidera klastera i prihvaćenosti lidera od svih članova klastera. Liderstvo u klasteru obuhvata koordiniranje raspodele znanja, edukaciju budućih lidera preduzeća i klastera, arbitriranje i stvaranje vizije i upravljanje promenama.

Prema I. R. Gordon-u i P. McCann-u (2005), razlikuju se tri grupe industrijskih klastera:

- čista aglomeracija,

- industrijski kompleksi, i

- socijalna mreža.

U prvom slučaju, relacije između preduzeća su u znatnoj meri prolazne, one su, u suštini, izdvojene, nemaju tržišnu moć i to pokušavaju da ostvare preko klastera. Kao rezultat toga, ne postoji dovoljan stepen lojalnosti između njih, kao i dugogodišnjih poslovnih odnosa. Kod industrijskog kompleksa, postoje dugoročni i stabilni odnosi između preduzeća u klasteru, zasnovani na finalnom proizvodu, kao, na primer, u automobilskoj i hemijskoj industriji. Članice klastera se udružuju radi pospešivanja dugoročnih investicija i minimizacije troškova transporta između njih. Treća grupa klastera su socijalne mreže, koje su zasnovane na izgradnji veza poverenja između usaglašenih $\mathrm{i}$ donetih odluka $\mathrm{u}$ preduzećima $\mathrm{u}$ klasteru. Time se smanjuju transakcioni troškovi između preduzeća u klasteru.

Prema S. A. Rosenfeld-u (2002), klastere karakterišu:

- sistematske veze između preduzeća,

- povezanost preduzeća na određenom georgafskom području,

- životni cikilus (embrionalno stanje, rast, zrelost, opadanje i gašenje),

- promenljivost članova (preduzeća),

- proizvode izlaz, i

- relacije između preduzeća.

Jedna od ključnih karakteristika klastera su relacije između članica klastera (preduzeća), koje zbog geografske udaljenosti zahtevaju da se preduzeća umreže primenom odgovarajućih ICT.

C. Wagner (2004) ukazuje na promene $u$ pogledu definisanja strategije u XXI veku: (1) kraći ciklusi planiranja i promene, (2) češće i značajnije promene $u$ preduzeću, često sa diskontinuitetom i (3) uključivanje delova preduzeća u lance snabdevanja, ili virtualne kompanije. U ovim, novim uslovima neophodno je razviti odgovarajući informacioni sistem, koji mora da obuhvati i podrži sve četiri faze u modelu zrelosti menadžmenta: finansijske planove, planiranje zasnovano na predviđanju, eksterno orijentisano planiranje i strategijski menadžment.

Softver za podršku strategijskom menadžmentu zasnovan je na rešenjima planiranja poslovnih resursa (Enterprise Resource Planning - ERP) sa ugrađenim zahtevima izbalansirane karte rezultata (Balanced Score Card-BSC), softverom za menadžment performansama preduzeća (Enterprise Performance Management - EPM) i softverom za ciklus izvršenja strategije preduzeća (Enterprise Strategy Execution Cycle - ESE).

Kompetencije su vezane za ljudske resurse koji, prema resursno baziranoj teoriji, utiču na poslovne performanse. Resursi vezani za ICT dele se na tri grupe: 
- opipljivi resursi (na primer, fizička ICT infrastruktura),

- ljudski ICT resursi (tehnička ICT znanja, menadžerska ICT znanja) i

- neopipljivi ICT resursi (znanje, orijentacija na kupca i sinergija).

J. Peppard i J. Ward (2004) su identifikovali šest domena kompetencija sa ukupno 26 vrsta kompetencija vezanih za ICT (Tabela 1).

Tabela 1 Podela kompetencija

\begin{tabular}{|c|c|}
\hline Domen kompetencija & ICT kompetencije \\
\hline Formulisanje strategije & $\begin{array}{l}\text { Poslovna strategija } \\
\text { Tehnološke inovacije } \\
\text { Kriterijumi investiranja } \\
\text { Upravljanje informacijama }\end{array}$ \\
\hline $\begin{array}{l}\text { Definisanje ICT } \\
\text { strategije }\end{array}$ & $\begin{array}{l}\text { Utvrđivanje prioriteta } \\
\text { Usklađivanje ICT strategije } \\
\text { Dizajn poslovnih procesa } \\
\text { Unapređenje poslovnih } \\
\quad \text { performansi } \\
\text { Inovacije sistema i procesa }\end{array}$ \\
\hline $\begin{array}{l}\text { Definisanje ICT } \\
\text { performansi }\end{array}$ & $\begin{array}{l}\text { Razvoj infrastrukture } \\
\text { Tehnološka analiza } \\
\text { Strategije pretraživanja }\end{array}$ \\
\hline Razrade i primena & $\begin{array}{l}\text { Planiranje koristi } \\
\text { Isporuka koristi } \\
\text { Upravljanje izmenama }\end{array}$ \\
\hline Rešenja isporuka & $\begin{array}{l}\text { Razvoj aplikacija } \\
\text { Menadžment uslugama } \\
\text { Menadžment informacionim } \\
\text { kapitalom } \\
\text { Menadžment primenama } \\
\text { Tehnologija primena } \\
\text { Kontinuitet poslovanja i } \\
\text { bezbednosti }\end{array}$ \\
\hline Dobavljači & $\begin{array}{l}\text { Veze sa dobavljačima } \\
\text { Tehnološki standardi } \\
\text { Akvizicija tehnologije } \\
\text { Menadžment osnovnim } \\
\text { sredstvima i troškovima } \\
\text { Razvoj osoblja za ICT }\end{array}$ \\
\hline
\end{tabular}

Izvor: Peppard \& Ward, 2004, 178-179
U Tabeli 2 su izdvojene ICT kompetencije za različite vrste ključne menadžerske prakse (Cragg, 2008, 32).

Treća grupa ICT kompetencija vezana je za ključnu tehničku praksu (Tabela 3) (Peppard \& Ward, 2004, 178).

U radu (Tanriverdi, 2006) analizirana je uloga ICT resursa i prakse menadžmenta kao izvor sinergije između poslovnih jedinica preduzeća. Sinergija između poslovnih jedinica preduzeća ostvaruje se uz podršku odgovarajuće ICT infrastrukture, realizacijom procesa donošenja ICT strategije, procesa menadžmenta odnosima $u$ vezi primene ICT i procesa menadžmenta ICT resursima. Autor je na uzorku od 165 industrijskih i 191 uslužnih preduzeća $(\mathrm{N}=365)$ prikazao da između navednih promenljivih postoji visoka korelacija sa kvalitetom primene ICT (faktori od 0,76 - 0,90), dok je uticaj primene ICT na performanse preduzeća znatno manji $(0,12)$. U ovom radu uspostavljen je model menadžmenta ICT resursima, koji je zasnovan na resursno baziranim teorijama. Autor je pošao od strategije, definisanja i nabavke potrebnog ICT rešenja. Nakon isporuke ICT rešenja, pratio je primenu ICT rešenja u praksi, kako bi na kraju ocenio doprinos ICT $\mathrm{u}$ ostvarivanju strategije. Na nivou ljudskih resursa, koji su povezani sa različitm ulogama, definišu se poslovne veštine, znanje i iskustvo, tehničke veštine, znanje i iskustvo i ponašanje i stavovi. Prema ovom modelu ICT strategija uravnotežava poslovne promene sa ICT pokretačima.

$\mathrm{Na}$ osnovu navedenih prethodnih istraživanja (Prytibok et al, 2008; Chen et al, 2011; Harton et al, 2010; Ngwenyama, \& Morawczynski, 2009; Cragg, 2008; Peppard \& Ward, 2004; Tanriverdi, 2006; Weil \& Ross, 2004), može se zaključiti da nivo ulaganja u ICT utiče direktno i indirektno (preko ICT strategije) na kvalitet primene ICT. U navedenim istraživanjima je, više ili manje, kroz različite studije slučajeva i teorijske analize dokazano da postoji pozitivni uticaj između nivoa ulaganja u ICT i kvaliteta primene ICT u preduzećima u okviru klastera, i to sa većim ili manjim koeficijentima regresije. Osnovna premisa je da su ulaganja svrsishodna, da su podržana ICT strategijom kao elementom korporativne strategije, i da kao ishodište imaju viši nivo kvaliteta primene ICT rešenja. 
Tabela 2 Ključni menadžerski faktori i uporedne ICT kompetencije

\begin{tabular}{|c|c|c|}
\hline Ključna mendžerska praksa & Opis prakse & Odgovarajuće (uporedne) ICT kompetencije \\
\hline Uloga ICT u poslovanju & $\begin{array}{l}\text { U vodećim preduzećima, ICT se posmatra } \\
\text { kao strategijsko okruženje u ostvarivanju } \\
\text { konkurentnosti, dok u nefleksibilnim } \\
\text { preduzećima ICT učestvuje u realizaciji procesa, } \\
\text { ali ne iznad konkurencije. Druga preduzeća } \\
\text { koriste ICT na operativnom nivou. }\end{array}$ & $\begin{array}{l}\text { - Poslovna strategija - obezbeđenje korišćenja } \\
\text { mogućnosti ICT } \\
\text { - Usklađivanje ICT strategije - obezbeđenje } \\
\text { uslova da se ICT planovi integrišu u strategi- } \\
\text { jski plan preduzeća }\end{array}$ \\
\hline $\begin{array}{l}\text { Podrška najvišeg } \\
\text { menadžmenta ICT }\end{array}$ & $\begin{array}{l}\text { U vodećim preduzećima, najviši menadžeri } \\
\text { su entuzijasti u vezi primene ICT i preuzima- } \\
\text { ju odgovornost za ICT projekte. U ostalim } \\
\text { preduzećima oni ignorišu zahteve ICT sve do } \\
\text { pojave krize. }\end{array}$ & $\begin{array}{l}\text { - Planiranje korisiti od investicija u ICT } \\
\text { - Upravljanje promenama - poslovne i organi- } \\
\text { zacione promene se realizuju u cilju maksimi- } \\
\text { zacije koristi bez uticaja na stakeholder-e }\end{array}$ \\
\hline $\begin{array}{l}\text { Menadžeri vide nove koristi } \\
\text { od ICT }\end{array}$ & $\begin{array}{l}\text { U vodećim preduzećima, strategijski menadž- } \\
\text { ment koristi mogućnosti ICT kroz internu i } \\
\text { eksternu komunikaciju. U ostalim preduzećima } \\
\text { to retko čine. }\end{array}$ & $\begin{array}{l}\text { - Tehnološka inovacija } \\
\text { - Inovacija sistema i procesa - razvoj ICT ap- } \\
\text { likacije za unapređenje procesa } \\
\text { - Tehnološka analiza - razmatranje tehnoloških } \\
\text { tendera i stvaranje preporuka za aktivaciju } \\
\text { novih ICT. }\end{array}$ \\
\hline
\end{tabular}

Izvor: Cragg, 2008, 32

Tabela 3 Ključni tehnički faktori i odgovarajuće ICT kompetencije

\begin{tabular}{lll}
\hline \multicolumn{1}{c}{ Ključna tehnička praksa } & \multicolumn{1}{c}{ Opis prakse } & \multicolumn{1}{c}{ Odgovarajuće ICT kompetencije } \\
\hline $\begin{array}{l}\text { Kastomizacija novih ICT } \\
\text { sistema }\end{array}$ & $\begin{array}{l}\text { Kod većih preduzeća, kastomizacija se obavez- } \\
\text { no i planski vrši, a kod ostalih vrlo retko. }\end{array}$ & $\begin{array}{l}\text { Razvoj aplikacija (razvoj i primena ICT rešenja i } \\
\text { zadovoljavanje poslovnih potreba). }\end{array}$ \\
\hline ICT specijalisti & $\begin{array}{l}\text { Kod ICT lidera rade ICT specijalisti koji su prošli } \\
\text { godine obuke i rada. Kod drugih preduzeća, } \\
\text { koriste se tehnički eksperti iz okruženja (out- } \\
\text { sourcing) }\end{array}$ & $\begin{array}{l}\text { Razvoj kadrova za ICT - prikupljanje, obuka i } \\
\text { raspoređivanje za potrebe preduzeća }\end{array}$ \\
\hline $\begin{array}{l}\text { Veštine razvoja informa- } \\
\text { cionih tehnologija }\end{array}$ & $\begin{array}{l}\text { Kod ICT lidera postoji najmanje jedna osoba } \\
\text { koja se bavi specijalnim oblastima u ICT (baze } \\
\text { podataka, softveri, hardver, mreže, itd.), a kod } \\
\text { ostalih preduzeća takva osoba ne postoji }\end{array}$ & $\begin{array}{l}\text { Primena tehnologije - na troškovno najefikas- } \\
\text { niji način kako bi se ostvarila korist od aplikacija }\end{array}$ \\
\hline
\end{tabular}

Izvor: Cragg, 2008, 33

\section{METODOLOGIJA ISTRAŽIVANJA}

Istraživanja $u$ ovom radu sprovedena su $u$ tri faze, korišćenjem odgovarajućih metodologija, i to:

- analiza referentnih literaturnih izvora za identifikaciju ključnih determinanti kvaliteta primene ICT rešenja,
- dizajniranje upitnika, slanje istih preduzećima, analiza validnosti dobijenih podataka i unos podataka u odgovarajuće tabele,

- primena statističkog softvera MATLAB i analiza signifikantnosti modela.

Osnova za analizu primene ICT rešenja je procesni model funkcionisanja preduzeća. 
Preduzeća u klasteru komuniciraju sa preduzećima unutar i van klastera primenom ICT. Primenom InputProces-Output (IPO) analize na preduzeća u klasteru, dobija se generički IPO model preduzeća (Slika 1). Prema IPO modelu, preduzeće se posmatra kao mreža procesa, koji međusobno komuniciraju pomoću ICT resursa. $\mathrm{U}$ ovom modelu procesi su grupisani $u$ tri generičke grupe procesa:

- procesi liderstva i menadžmenta,

- procesi realizacije, $\mathrm{i}$

- procesi podrške.
Dominantna komunikacija ostvaruje se između generičkih procesa unutar preduzeća, uz ICT podršku komunikacijama. Primena ICT podrške omogućava i eksternu komunikaciju na osnovu menadžmenta ulazima i izlazima iz preduzeća. Ulazi i izlazi iz preduzeća se posebno analiziraju za sve grupe procesa, kao i za svaki proces posebno. Ovaj opšti generički model funkcionisanja preduzeća omogućava formiranje modela kvaliteta primene ICT. Na osnovu analizirane referentne literature, iz definisanih generičkih procesa u IPO modelu, izdvojene su sledeće varijable, koje su uključene u model:

- procesi liderstva i menadžmenta

$\mathrm{V}_{1}$ - nivo ulaganja u ICT,

$\mathrm{V}_{2}$ - kvalitet menadžmenta,

$\mathrm{V}_{3}$ - nivo kvaliteta procesa, $\mathrm{i}$

$\mathrm{V}_{4}$ - nivo ICT strategija

- procesi realizacije

$\mathrm{V}_{3}$ - nivo kvaliteta procesa

- procesi podrške

Y - nivo kvaliteta primene ICT.

Na Slici 2 prikazan je početni model kvaliteta primene ICT. U ovom modelu varijabla $Y$ je definisana kao

Slika 1 Generički IPO model preduzeća

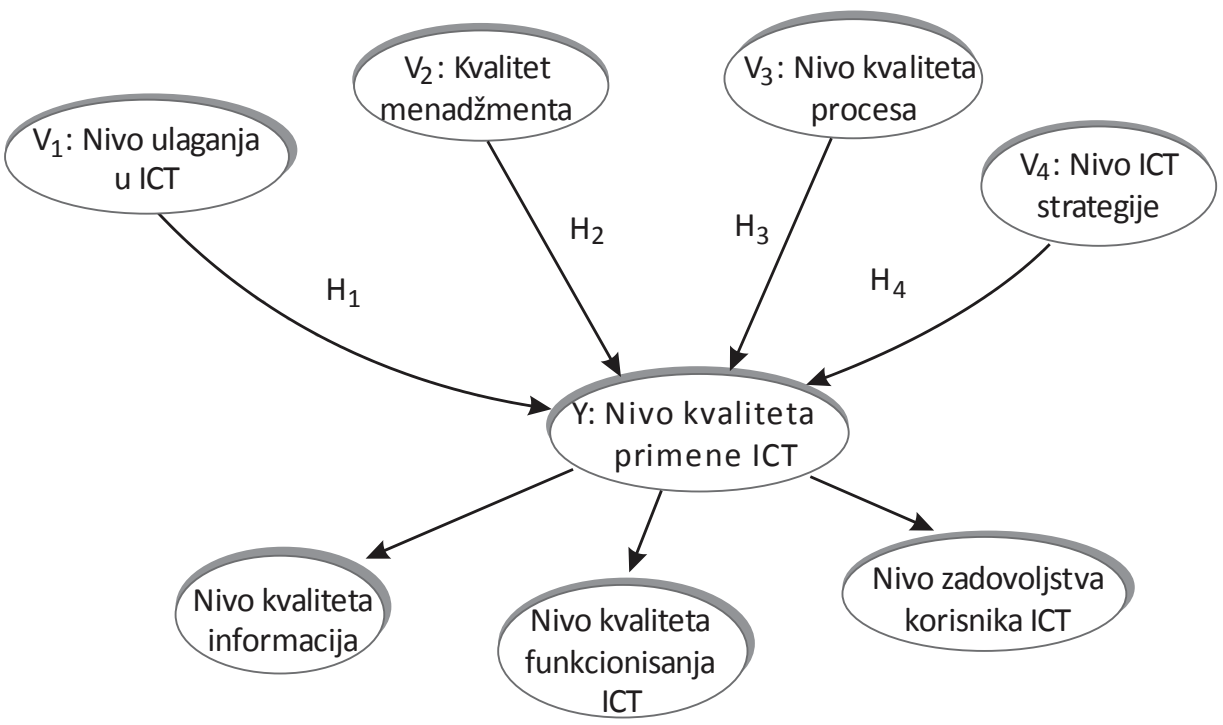

Slika 2 Model kvaliteta primene ICT 
agregatna mera, na osnovu podataka o nivoima kvaliteta informacija, kvaliteta funkcionisanja ICT i zadovoljstva korisnika ICT.

Nivo ulaganja u ICT $\left(\mathrm{V}_{1}\right)$, utvrđen je na osnovu udela ulaganja u ICT $\mathrm{u}$ odnosu na ukupne investicije $\mathrm{u}$ organizaciji, prosečno na godišnjem nivou i izražen $\mathrm{u}$ procentima. Preko odgovarajuce metrike to je prevedeno u odgovarajuću ocenu na skali od 1 do 10.

Nivo kvaliteta menadžmenta $\left(\mathrm{V}_{2}\right)$ ocenjuje se kao kvalitet procesa menadžmenta, komponovanog iz sledećih potprocesa:

$\mathrm{P}_{0} 1$ - Planiranja,

$\mathrm{P}_{0} 2$ - Organizovanja,

$\mathrm{P}_{0} 3$ - Kontrolisanja, $\mathrm{i}$

$\mathrm{P}_{0} 4$ - Vođenja.

Kvalitet procesa $\left(V_{3}\right)$ utvrđuje se na osnovu metrike za svaki proces posebno (marketing, prodaja, nabavka, itd.) i izražava se na nivou organizacije za sve procese u celini.

ICT strategija $\left(\mathrm{V}_{4}\right)$ je, takođe, posmatrana kao proces, čiji se nivo određuje na osnovu:

- kvaliteta planova za ostvarivanje strateških ciljeva ICT,

- kvaliteta strategije/planova za unapređenje zadovoljstva korisnika ICT,

- kvaliteta planova ljudskih resursa za ICT,

- kvaliteta alokacije resursa za efektivan rad ICT i

- kvaliteta odnosa sa partnerima, isporučiocima i vendorima ICT opreme.

Kvalitet primene ICT (Y) posmatra se kao trijada sledećih aspekata:

- kvalitet informacija, baziran na sadržaju, raspoloživosti, tačnosti, pravovremenosti, konciznosti i pogodnosti za promenu,

- kvalitet funkcionisanja ICT, baziran na pouzdanosti, lakoći korišćenja, mogućnosti pristupa, korisnosti i fleksibilnosti, i

- zadovoljstvo korisnika ICT (internih i eksternih), baziran na pouzdanosti dobijanja tražene usluge, brzini pravog odgovora, empatiji i kompetentnosti za dobijene informacije.

Uticaj nivoa ulaganja u ICT $\left(\mathrm{V}_{1}\right)$ analiziran je u mnogim teorijskim i aplikativnim istraživanjima, od kojih su posebno korišćeni (Tonchia \& Tramontano, 2004; Aikens 2011; Prytibok et al, 2008; O'Brien \& Marakas, 2011). Većina ovih istraživanja odnosila su se na srednja i veća preduzeća, sa višim nivoom zrelosti i iskustva u primeni ICT. Utvrđeno je da postoji pozitivna relacija čiji inzenzitet varira od mnogih faktora.

Na osnovu prethodnih analiza i postavljenog početnog modela kvaliteta primene ICT, postavljena je osnovna hipoteza o sinergijskom efektu determinanti kvaliteta primene ICT:

$\mathrm{H}_{0}$ : Nivo ulaganja u ICT $\left(\mathrm{V}_{1}\right)$, nivo kvaliteta menadžmenta $\left(\mathrm{V}_{2}\right)$, nivo kvaliteta procesa $\left(\mathrm{V}_{3}\right)$ i nivo ICT strategije $\left(\mathrm{V}_{4}\right)$, imaju pozitivan uticaj na egzogeno promenljivu - nivo kvaliteta primene ICT (Y).

Pored osnovne hipoteze, zbog specifičnosti privrednog ambijenta u RS, postavljene su pomoćne hipoteze, koje treba da ukažu na signifikantnost uticaja svake navedene determinante na kvalitet primene ICT:

$\mathrm{H}_{1}$ : nivo ulaganja u ICT $\left(\mathrm{V}_{1}\right)$ ima pozitivan uticaj na nivo kvaliteta primene ICT $(\mathrm{Y})$;

$\mathrm{H}_{2}$ : nivo kvaliteta menadžmenta $\left(\mathrm{V}_{2}\right)$ ima pozitivan uticaj na nivo kvaliteta primene ICT (Y);

$\mathrm{H}_{3}$ : nivo kvaliteta procesa $\left(\mathrm{V}_{3}\right)$ ima pozitivan uticaj na nivo kvaliteta primene ICT $(\mathrm{Y})$;

$\mathrm{H}_{4}$ : nivo ICT strategije $\left(\mathrm{V}_{4}\right)$ ima pozitivan uticaj na nivo kvaliteta primene ICT $(\mathrm{Y})$

Hipoteza $\mathrm{H}_{1}$ odnosi se na uticaj nivoa ulaganja $\mathrm{u}$ ICT $\left(\mathrm{V}_{1}\right)$ na kvalitet primene ICT $(\mathrm{Y})$, respektujući okolnosti da u mnogim preduzećima u RS ne postoji definisana ICT strategija, posebno u grupi malih i srednjih preduzeća (Roztocki \& Weistroffer, 2011; Themistocleous et al, 2011; Stefanović, 2005; Republički zavod za statistiku, 2012), koja čine preko 90\% svih preduzeća.

Hipoteza $\mathrm{H}_{2}$ odnosi se na uticaj kvaliteta menadžmenta na nivo kvaliteta primene ICT. Na osnovu referentnih 
literaturnih izvora (Arsovski et al, 2009), koji se odnose na menadžment informacione sisteme (Management Information Systems - MIS) i menadžment kvalitetom (Aikens, 2011; Evans, 2011; Oukland, 2004), hipoteza $\mathrm{H}_{2}$ odnosi se na direktan uticaj nivoa kvaliteta menadžmenta $\left(\mathrm{V}_{2}\right)$ na kvalitet primene ICT $(\mathrm{Y})$. Pretpostavka za ovu relaciju je relativno visok nivo kvaliteta menadžmenta i ulaganja u ICT, što je izuzetak za poslovni ambijent u RS. Rezultate istraživanja treba proveriti u realnim domaćim uslovima, gde je relativno nizak nivo kvaliteta menadžmenta (Arsovski et al, 2012) i ICT strategije (Arsovski et al, 2012; Stefanović et al, 2012).

Hipoteza $\mathrm{H}_{3}$ odnosi se na uticaj nivoa kvaliteta procesa $\left(\mathrm{V}_{3}\right)$ na nivo kvaliteta primene ICT $(\mathrm{Y})$. Ova hipoteza je istraživana u preduzećima u razvijenim zemljama i dokazana je u referentnoj literaturi (Prytibok et al, 2008; Wagner, 2004; Wieder et al, 2006). Istraživanja koja se sprovode u preduzećima u domaćoj privredi treba da potvrde vrednost veličine koeficijenta regresije kod ove relacije.

Hipoteza $\mathrm{H}_{4}$ odnosi se na uticaj kvaliteta ICT strategije $\left(\mathrm{V}_{4}\right)$ na nivo kvaliteta primene ICT $(\mathrm{Y})$, koja je višestruko potvrđena, pre svega, $u$ istraživanjima inostranih autora u oblasti ICT (Turban et al, 2006; Laudon \& Traver, 2008; Prytibok et al, 2008; Wagner, 2004; Cragg, 2002). U domaćim uslovima, sa relativno nižim nivoom varijabli $V_{3}$ i $V_{4}$, potrebno je istražiti vrednost veličine koeficijenta regresije kod ove relacije.

Upitnik, $\mathrm{u}$ kome su definisane varijable $\mathrm{V}_{1}, \mathrm{~V}_{2}, \mathrm{~V}_{3}, \mathrm{~V}_{4} \mathrm{i}$ $Y$, podaci o klasterima, preduzećima i korespondentnoj osobi, poslat je izabranim preduzećima (ukupno 150). Anketirana preduzeća su unosila ocene o nivoima varijabli, koji su definisani na skali od 1 do 10, gde je ocena 1 najniža, a ocena 10 najviša za svaku varijablu. $\mathrm{Na}$ osnovu ovih ocena formirana je baza podataka sa tabelama o modelima, klasterima, preduzećima, varijablama, upitnicima i statističkim softverima (Slika 3).

Na osnovu prikupljenih podataka iz pristiglih 74 upitnika (procenat odgovora oko 49\%), ažurirana je prethodno kreirana baza podataka.

\section{REZULTATI ISTRAŽIVANJA}

Na osnovu postavljenog modela kvaliteta primene ICT, koji je prikazan na Slici 2, definisana je zavisnost $Y$ (kvalitet primene ICT) od nezavisnih promenljivih (varijabli $\mathrm{V}_{1}, \mathrm{~V}_{2}, \mathrm{~V}_{3} \mathrm{i}_{4}$ ):

$Y=a_{0}+a_{1} V_{1}+a_{2} V_{2}+a_{3} V_{3}+a_{4} V_{4}$

gde su:

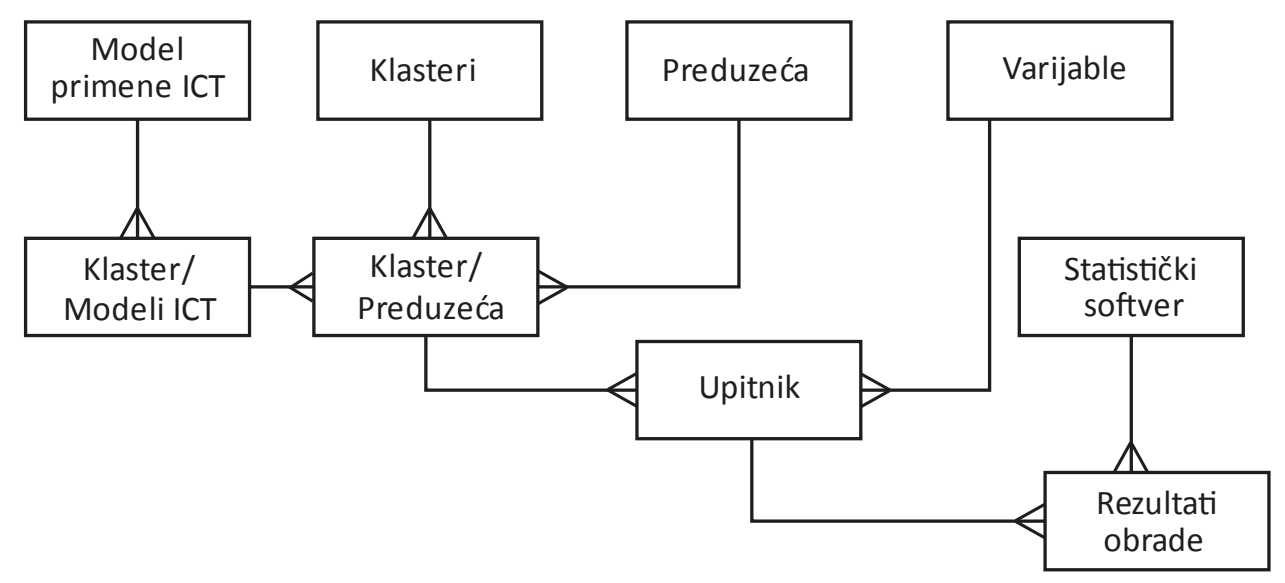

Slika 3 Struktura baze podataka "Determinante primene ICT" 
$a_{i}(i=0-4)-$ konstante dobijene postupkom višestruke regresije

$\mathrm{V}_{1}$ - nivo ulaganja u ICT,

$\mathrm{V}_{2}$ - nivo kvaliteta menadžmenta,

$\mathrm{V}_{3}$ - nivo kvaliteta procesa,

$\mathrm{V}_{4}-$ nivo ICT strategije.

Definisan model kvaliteta primene ICT je ispitivan na uzorku od 74 preduzeća, gde je analizirana tačnost i pouzdanost podataka, a u Tabeli 4 prikazani su obrađeni podaci o veličini preduzeća po broju zaposlenih i oblasti poslovanja.

Postupak statističke analize realizovan je $\mathrm{u}$ tri koraka. U prvom koraku ispitano je da li postoji zavisnost između nezavisno promenljivih u modelu, na osnovu utvrđivanja Pearson-ovog koeficijenta korelacije. U drugom koraku, utvrđena je korelacija između svake nezavisne promenljive $\left(V_{1}, V_{2}, V_{3} i V_{4}\right)$ i zavisne promenljive $(\mathrm{Y})$. U trećem koraku, primenom višestruke regresione analize utvrđena je ukupna korelacija (kao rezultat sinergijskog efekta) između svih nezavisno promenljivih $\left(\mathrm{V}_{1}, \mathrm{~V}_{2}, \mathrm{~V}_{3} \mathrm{i} \mathrm{V}_{4}\right)$ i zavisno promenljive $(\mathrm{Y})$.

Analizom dobijenih odgovora od 74 preduzeća, utvrđeno je da postoje neusaglašenosti kod 21 preduzeća, pa je ukupan uzorak sveden na 53 preduzeća u klasteru. Struktura konačnog uzorka, prema oblasti poslovanja i broju zaposlenih, data je $\mathrm{u}$ Tabeli 4 gde prvi broj ukazuje na početni uzorak od 74 preduzeća, a broj iza kose crte ukazuje na konačni uzorak od 53 preduzeća. Nakon toga, ažurirana je baza podataka sa proverenim i validnim podacima, nad kojom je, primenom softverskog paketa MATLAB, sproveden postupak višestruke linearne regresije (2):

$Y_{i}=\beta_{0}+\sum \beta_{i j} X_{j}+\varepsilon_{i}$

gde su:

$Y_{i}$ - zavisna (endogena) promenljiva,

$X_{i}$ - regresor (egzogena, tranzitivna ili nezavisna promenljiva), $\mathrm{i}$

$\varepsilon_{\mathrm{i}}-$ neutvrđena slučajna promenljiva (greška, šum).

$\mathrm{S}$ obzirom da $\mathrm{u}$ modelu egzistira više promenljivih $(\mathrm{i}=3)$, primenom Fisher-ove $(\mathrm{F})$ statistike utvrđene su relacije u modelu i potvrđeno je:

- da ne postoji linearna korelisanost između nezavisnih promenljivih $\mathrm{V}_{1}, \mathrm{~V}_{2}, \mathrm{~V}_{3}$ i $\mathrm{V}_{4}$ (Pearsonov koeficijent korelacije za sve promenljive, koje se kreću u rasponu od 0,042619 do 0,198618, što je manje od granične vrednosti za uzorak od 53 preduzeća, koji iznosi 0,27 za nivo signifikantnosti od $5 \%)$, i

- da između svih parova u modelu (nezavisno promenljivih $-V_{i}, i=1-4$, i zavisno promenljive $-Y$ ) postoji značajna korelacija izražena Pearson-ovim koeficijentima, koji se kreću u rasponu od 0,403503 do 0,439053 , što je veće od granične vrednosti od 0,27 za nivo signifikantnosti od $5 \%$.

Ključna hipoteza istraživanja $\mathrm{H}_{0}$ odnosi se na sinergijski efekat uticaja promenljivih $\mathrm{V}_{1}, \mathrm{~V}_{2}, \mathrm{~V}_{3}$ i $\mathrm{V}_{4}$ na kvalitet primene ICT (Y). Statističkom obradom

Tabela 4 Struktura preduzeća u istraživanom klasteru prema oblasti poslovanja i broju zaposlenih

\begin{tabular}{l|cccccc}
\hline Broj zaposlenih Oblast & $\begin{array}{c}\text { Industrija hleba } \\
\text { i peciva }\end{array}$ & $\begin{array}{c}\text { Proizvodnja vode i } \\
\text { tečnih napitaka }\end{array}$ & $\begin{array}{c}\text { Prerada } \\
\text { mesa }\end{array}$ & Usluge & $\begin{array}{c}\text { Prateća } \\
\text { industrija }\end{array}$ & Ukupno \\
\hline $0-9$ & $30 / 25$ & $1 /-$ & - & $10 / 4$ & $3 / 2$ & $44 / 33$ \\
$10-49$ & $2 / 2$ & $1 / 1$ & $1 / 1$ & $5 / 3$ & $3 / 2$ & $12 / 9$ \\
$50-125$ & $1 / 1$ & $2 / 2$ & $2 / 2$ & $3 / 1$ & $3 / 2$ & $11 / 8$ \\
$125-250$ & - & $1 / 1$ & $1 / 1$ & $1 / 1$ & $1 /-$ & $4 / 3$ \\
$>250$ & - & $3 / 2$ & - & - & - & $3 / 2$ \\
Ukupno & $33 / 28$ & $8 / 6$ & $4 / 4$ & $19 / 9$ & $10 / 6$ & $74 / 53$ \\
\hline
\end{tabular}


podataka, u okviru ovog istraživanja, dobijena je zavisnost (3) sa ukupnim koeficijentom korelacije od 0,4768 , koji je veći od najvećeg pojedinačnog koeficijenta korelacije izmedju $V_{1}$ i $Y(0,439053)$ :

$$
\begin{aligned}
\mathrm{Y} & =-6,3668+0,3388 * \mathrm{~V}_{1}+0,6759 * \mathrm{~V}_{2}+ \\
& +0,4461 * \mathrm{~V}_{3}+0,3854 * \mathrm{~V}_{4}+\mathrm{e} \\
\mathrm{R}^{2} & =0,4768, \mathrm{e}=2,4071
\end{aligned}
$$

Relacija (3) je rezultat korišćenja relacije (2), koja se odnosi na višestruku linearnu regresiju, ima značajnu statističku signifikantnost, jer varijable $V_{1}, V_{2}, V_{3}$ i $\mathrm{V}_{4}$ sa koeficijentom korelacije $\mathrm{R}^{2}=0,4768$ utiču na varijablu $\mathrm{Y}$. Najveći uticaj ima varijabla $\mathrm{V}_{2}$ sa faktorom 0,6759 (kvalitet menadžmenta), sledi nešto manji uticaj varijable $V_{3}$ sa faktorom 0,4461 (nivo kvaliteta procesa) $i$, na kraju, znatno manji uticaj varijable $V_{1}$ (nivo ulaganja u ICT) i $V_{4}$ (nivo ICT strategije) na varijablu $Y$ (kvalitet primene ICT).

Na slikama 4, 5, 6 i 7 prikazane su zavisnosti determinanti primene ICT na kvalitet primene ICT, dobijene postupkom jednostruke linearne regresije.

Analizom relacije prikazane na Slici 4 može se zaključiti da je hipoteza $\mathrm{H}_{1}$ dokazana, sa značajnom vrednošću Pearson-ovog koeficijenta korelacije $\mathrm{R}=0,439053$.

Hipoteza $\mathrm{H}_{2}$ je dokazana, jer je utvrđena vrednost Pearson-ovog koeficijenta korelacije $\mathrm{R}=0,403503$, što je znatno više od granične vrednosti koja iznosi 0,27 za nivo signifikantnosti od 5\% (Slika 5).

Uticaj $\mathrm{V}_{3}$ na $\mathrm{Y}$ (hipoteza $\mathrm{H}_{3}$ ), koja je prikazana na Slici 6, potvrđena je $\mathrm{u}$ ispitivanom uzorku, jer je utvrđena vrednost Pearson-ovog koeficijenta korelacije od $\mathrm{R}=0,411596$.

Analizom uticaja $\mathrm{V}_{4}$ na $\mathrm{Y}$ (hipoteza $\mathrm{H}_{4}$ ), koja je prikazana na Slici 7, utvrđeno je da Pearson-ov koeficijent korelacija iznosi $\mathrm{R}=0,403932$, čime je potvrđena hipoteza $\mathrm{H}_{4}$.

Dakle, potvrđene su parcijalne hipoteze $\mathrm{H}_{1}$ $(\mathrm{R}=0,439053), \mathrm{H}_{2}(\mathrm{R}=0,403503), \mathrm{H}_{3}(\mathrm{R}=0,411596)$ i $_{4}(\mathrm{R}=0,403932)$, kao i glavna hipoteza $\mathrm{H} 0$, koja ukazuje na ukupan uticaj promenljivih $\mathrm{V}_{1}, \mathrm{~V}_{2}, \mathrm{~V}_{3} \mathrm{i}$ $\mathrm{V}_{4}$ na zavisnu promenljivu $\mathrm{Y}(\mathrm{R}=0,4768)$, pri čemu je ostvaren sinergijski efekat varijabli u modelu.

Relativno visok koeficijent varijacije kod varijabli $\mathrm{V}_{1}$ i Y ukazuje na to da su ovo promenljive kod kojih je

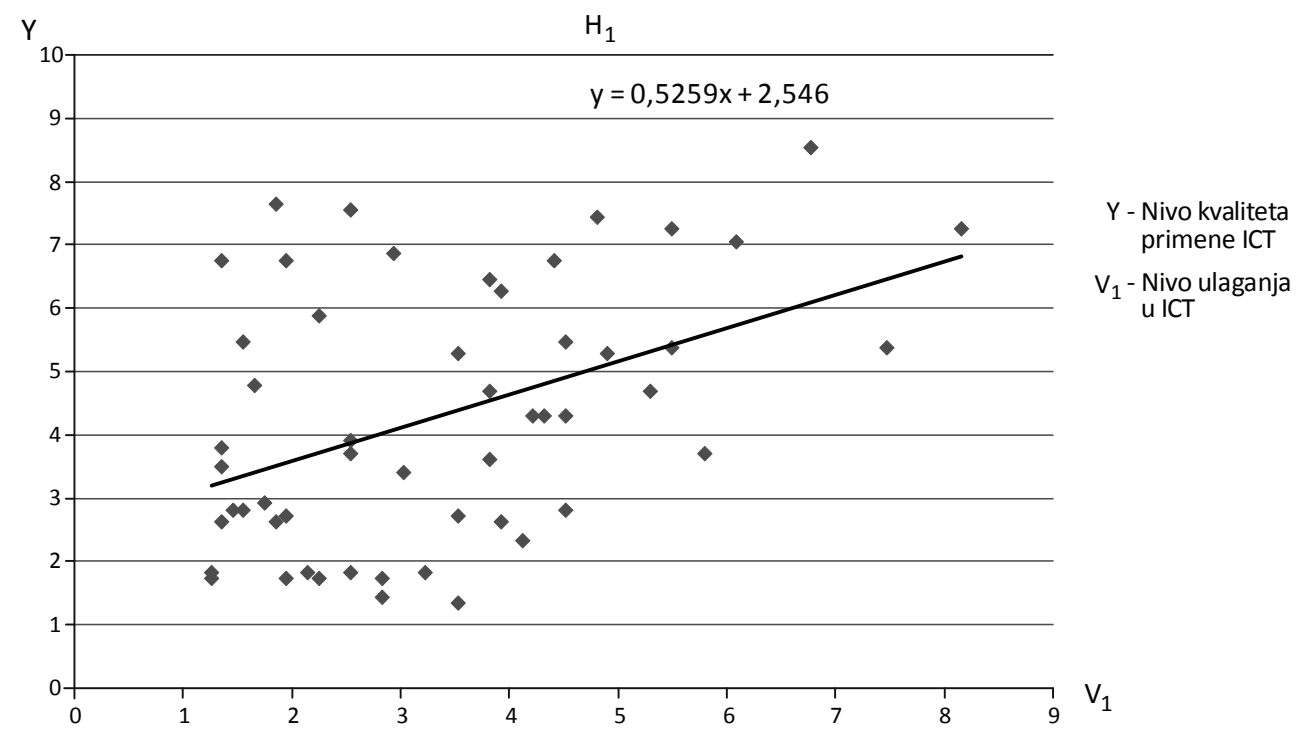

Slika 4 Zavisnost nivoa kvaliteta primene ICT (Y) od nivoa ulaganja u ICT (V1) 
udeo šuma statistički vrlo visok, što umanjuje tačnost predikcije ponašanja u početnom modelu. To se moglo očekivati jer preduzeća u klasteru raspolažu različitim nivoima ICT, što zahteva različite nivoe ulaganja u ICT.
Analizom uticaja varijabli $V_{2}$ na $Y$, što je prikazano na Slici 5, može se zaključiti da postoji pozitivan uticaj $(\mathrm{R}=0,403503)$, koji se može povećati uvođenjem dodatnih varijabli (u ovom slučaju, to je varijabla nivo znanja menadžmenta o ICT).

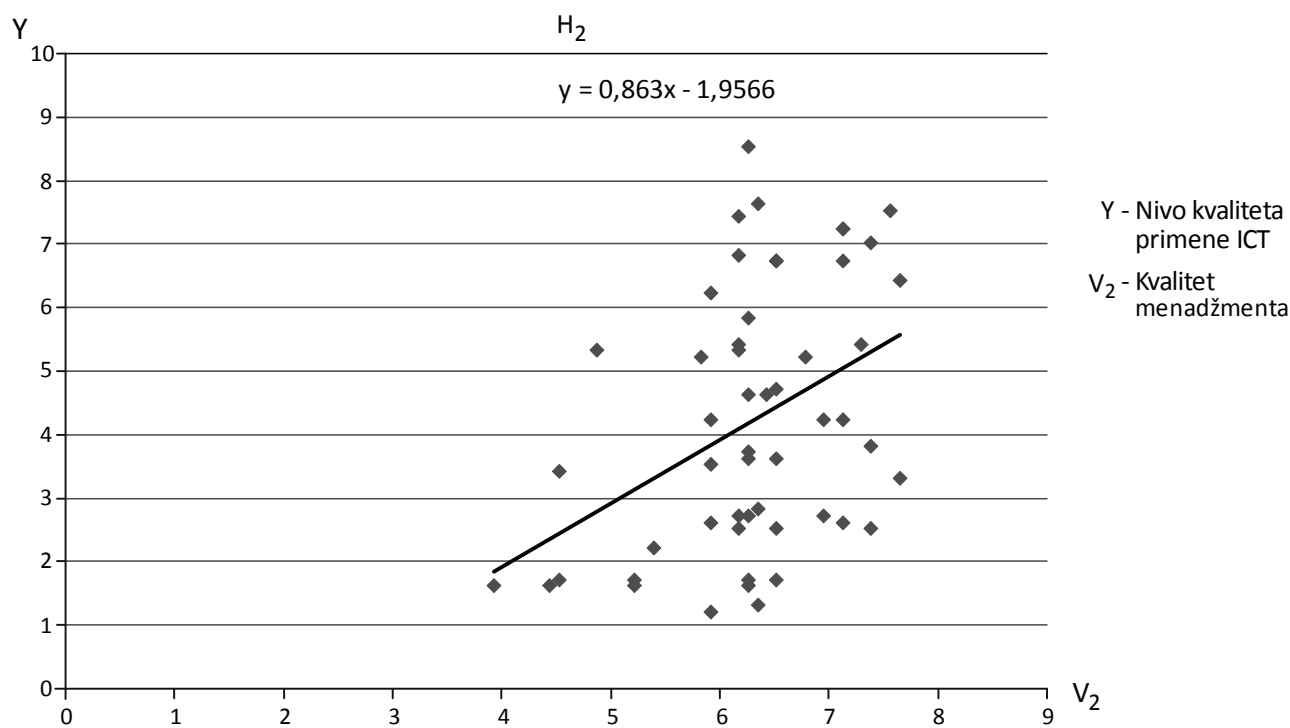

Slika 5 Zavisnost nivoa kvaliteta primene ICT (Y) od kvaliteta menadžmenta (V2)

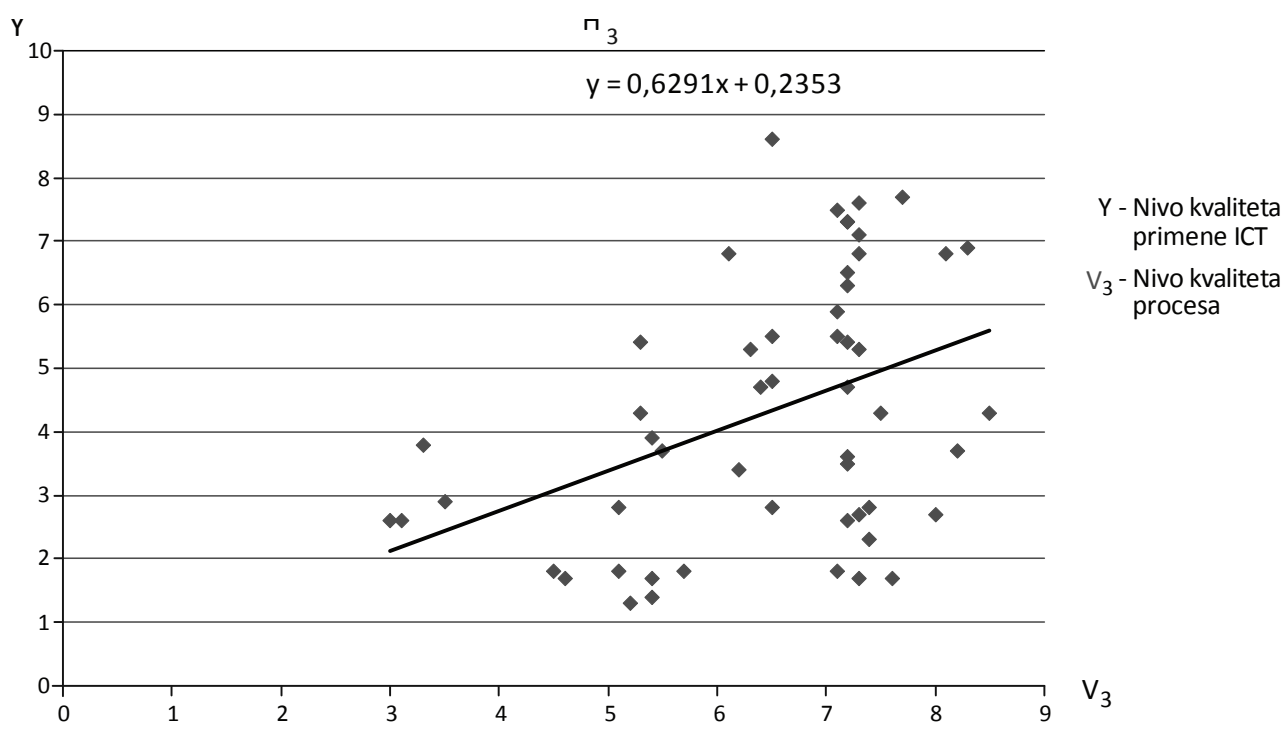

Slika 6 Zavisnost nivoa kvaliteta primene ICT (Y) od nivoa kvaliteta procesa (V3) 


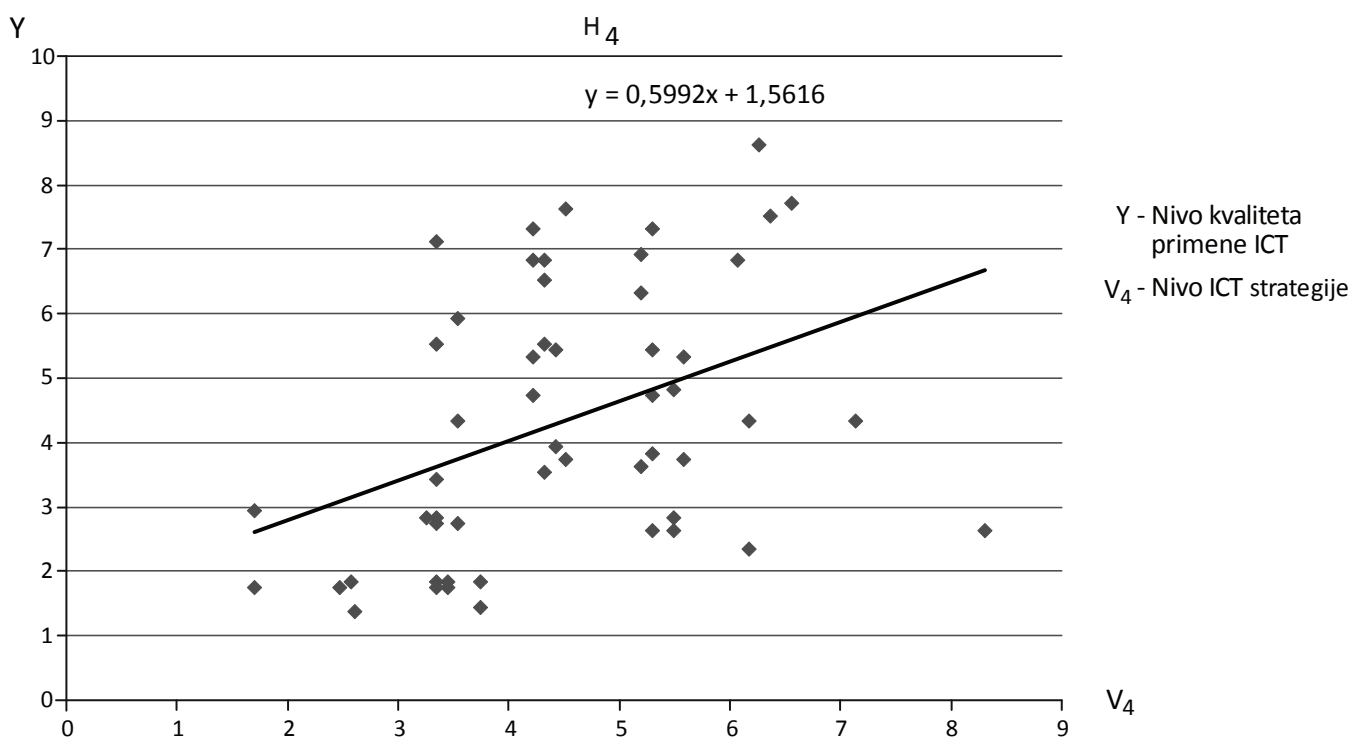

Slika 7 Zavisnost nivoa kvaliteta primene ICT (Y) od nivoa ICT strategije (V4)

U Tabeli 5 date su srednje vrednosti i standardne devijacije za sve varijable u modelu $\left(\mathrm{V}_{1}, \mathrm{~V}_{2}, \mathrm{~V}_{3}, \mathrm{~V}_{4}, \mathrm{i} \mathrm{Y}\right)$, potrebne za ocenu koeficijenta varijacije.

Tabela 5 Srednje vrednosti i standardne devijacije varijabli u modelu

\begin{tabular}{lccccc}
\hline \multicolumn{1}{c}{$\begin{array}{c}\text { Varijable } \\
\text { Rezultati }\end{array}$} & $V_{1}$ & $V_{2}$ & $V_{3}$ & $V_{4}$ & $Y$ \\
\hline $\begin{array}{l}\text { Srednja vred- } \\
\text { nost }\end{array}$ & 3.328 & 7.245 & 6.454 & 4.564 & 4.296 \\
$\begin{array}{l}\text { Standardna } \\
\text { devijacija }\end{array}$ & 1.720 & 0,963 & 1.348 & 1.389 & 2.060 \\
\hline
\end{tabular}

Na osnovu analize rezultata istraživanja, početni model primene ICT je, na posmatranom uzorku, potvrdio hipoteze $\mathrm{H}_{1}, \mathrm{H}_{2}, \mathrm{H}_{3}, \mathrm{H}_{4}$ i glavnu hipotezu $\mathrm{H}_{0}$ o uticaju varijabli $V_{1}, V_{2}, V_{3}$ i $V_{4}$ na varijablu $Y$ (nivo primene ICT). Na osnovu izraza (3), zaključuje se da najveći uticaj na varijablu $\mathrm{Y}$ ima $\mathrm{V}_{2}$ (kvalitet menadžmenta sa faktorom 0,6759 ), a zatim varijabla $V_{3}$ (nivo kvaliteta procesa sa faktorom 0,4461). S obzirom na ograničene finansijske resurse $u$ klasterima preduzeća $u R S, u$ ovom trenutku značajnije povećanje kvaliteta primene
ICT (Y) može se očekivati, pre svega, povećanjem varijable $V_{2}$ i $V_{3}$ i to bez značajnih investicionih ulaganja. Ukoliko bi se postiglo povećanje varijabli $V_{2}$ za $20 \%$ i $\mathrm{V}_{3}$ za $10 \%$, ukupna vrednost varijable $\mathrm{Y}$ bila bi povećana za $29,6 \%$.

Ako se uzme $u$ obzir da uticaj $Y$ na performanse preduzeća, prema (Pritybok et all, 2008, 149), iznosi 0,79 , u klasterima preduzeća u RS može se očekivati povećanje neto koristi od primene ICT do $20 \%$ i to bez značajnijih ulaganja.

\section{ZAKLJUČAK}

Problem primene ICT prepoznat je od početka informacione ere. Rešenje ovog problema traženo je u više oblasti, kao što su tehnološka, ljudski resursi, obrazovanje, menadžment, ekonomski, itd. U brojnim studijama ukazano je na ključne determinante i nivoe njihovog uticaja na različite aspekte primene ICT u preduzećima. Pri tome su analizirane dve grupe problema: uticaj ICT na performanse preduzeća i uticaj eksternih i internih pokretača na ponašanje primene ICT u preduzećima. Ovaj rad je usmeren na rešavanje ove druge grupe problema, posebno kod malih i srednjih preduzeća, povezanih slabim vezama u klaster. 
Polazeći od teorije i prakse orgnizovanja klastera, $\mathrm{u}$ radu su analizirana 53 preduzeća, povezana $u$ klaster sa slabim vezama, $\mathrm{u}$ kome su dominantno bila zastupljena mala i srednja preduzeća. Sastav ovog uzorka približno odražava sastav industrije u Srbiji. Na osnovu razvijenog modela primene ICT definisan je upitnik sa odgovarajućom strukturom pitanja, koja ukazuju na vrednosti izabranih varijabli u tom preduzeću. Na osnovu referentne literature izdvojene su četiri determinante kao varijable: (1) nivo ulaganja u ICT, (2) nivo kvaliteta menadžmenta, (3) nivoa kvaliteta procesa, i (4) nivo ICT strategije, koji utiču direktno i indirektno na zavisno promenljivu (nivo kvaliteta primene ICT). Zbog dominantnog učešća malih preduzeća, dobijena je jedna ocena za svaku promenljivu u preduzeću, od strane menadžmenta/ vlasnika, što je prouzrokovalo veće rasipanje vrednosti u uzorku. Poredeći dobijene vrednosti sa referentnim radovima iz ove oblasti, koeficijent varijacije je $15-40 \%$, što je nešto više od uobičajenog, zbog razlika u veličini organizacije, položaja grane industrije i pretežno lokalne konkurencije.

Najveći doprinos rada je u utvrđivanju uticaja promenljivih: ulaganje u ICT $\left(\mathrm{V}_{1}\right.$ - faktor uticaja $0,3388)$, kvalitet menadžmenta $\left(\mathrm{V}_{2}\right.$ - faktor uticaja $0,6759)$, kvalitet procesa $\left(\mathrm{V}_{3}\right.$ - faktor uticaja 0,4461$)$ i ICT strategije (V4 - faktor uticaja 0,3854). Ova relacija se može iskoristiti za simuliranje efekata unapređenja na ponašanje primene ICT $\mathrm{u}$ praksi. $\mathrm{S}$ obzirom na relativno niska postojeća ulaganja u ICT, sa neznatnim ulaganjima mogu se očekivati znatno bolje performanse primene ICT u praksi, a time i unapređene performanse preduzeća. Ovaj pristup se može analogno primeniti i na unapređenje ICT strategije, koja postoji u većini preduzeća samo na početnom nivou, pri čemu je za njeno unapređenje potrebno angažovati eksperte van preduzeća. Treća po uticaju je promenljiva, koja se odnosi na kvalitet procesa u preduzeću. Unapređenje ove promenljive ostvaruje se uvođenjem standardizovanih sistema menadžmenta (ISO 9001, ISO 20000, ISO 27000 i dr.), specifikacija i sektorskih standarda (HACCP, Informaciona arhitektura, eTOM, i dr.) i principa dobre proizvodnje. Za unapređenje vredenosti ove varijable nisu potrebna značajna ulaganja.
Ograničenja $u$ ovom radu odnose se na veličinu uzorka, strukturu klastera preduzeća, kao i nizak nivo primene savremenih ICT u preduzećima $\mathrm{u}$ klasteru. Veličina klastera je ograničena brojem postojećih preduzeća u klasterima preduzeća u Srbiji, ali se uzorak u ovom istraživanju od 53 preduzeća može, u budućim istraživanjima, proširiti do 90 preduzeća, pa se preduzeća u povećanom uzorku klastera mogu grupisati prema veličini preduzeća i oblasti poslovanja. Očekuje se da rezultati budućih istraživanja, nad ovakvim uzorkom, budu sa većim koeficijentom korelacije i boljom predikcijom ponašanja preduzeća $u$ klasteru.

Ostvareni rezultati istraživanja i prevladavanje navedenih ograničenja, predstavljaće dobru osnovu za nova istraživanja u sledećim oblastima: (1) uključivanje kontrolnih promenljivih, kao što su veličina preduzeća, karakteristike poslovanja, starost preduzeća, konkurentnost, (2) definisanje proširenog modela primene ICT u praksi na osnovu dodatnog sistema pokazatelja, (3) razvoj simulacionog softvera za ocenu uticaja ICT na performanse preduzeća i (4) poredjenje nivoa kvaliteta primene ICT $\mathrm{u}$ različitim klasterima preduzeća u Republici Srbiji.

\section{ZAHVALNICA}

Ovaj rad je deo interdisiplinarnog i multidisciplinarnog istraživačkog Projekta (br. 44010), koji finansira Ministarstvo nauke Republike Srbije.

\section{REFERENCE}

Aikens, C. H. (2011). Quality Inspired Management: The Key to Sustainability. USA: Prentice Hall, Boston.

Albright, S. C., Zappe, C., \& Winston, W. (2011). Data Analysis, Organization and Simulation Modeling. Canada: South Western Cengage Learning.

Arsovski, Z., Arsovski, S., Mirović, Z., \& Stefanović, M. (2009). Simulation of quality goals: A missing link between corporate strategy and business process management. International Journal for Quality Research, 4(1), 449-459. 
Arsovski, Z., Arsovski, S., Ranković, V., Kalinić, Z., Rejman Petrović, D., \& Milanović, I. (2012). Quality Concept in Enterprise Management. In A. Malina, R. Oczkowska, T. Rojek, (Eds.), Knowledge, Economy Society - Dilemmas of the Contemporary Management (pp. 501-516). Cracow: Cracow University of Economics.

Arsovski, Z., Arsovski, S., \& Nikezić, S. (2012). Developement of quality management in enterprises of Serbia. Journal of Technics Tehnologies Education Management, 7(2), 944-949.

Berghmans, P., \& Roy, K. (2011). Information security risks in enabling e-goverment: The impact of IT Vendors. Information System Management, 28(4), 284-293. DOI: $10,1080 / 10580530,2010,514212$

Becker, J. (2003). Process Management. Berlin: Spriger.

Brah, A. S., \& Lim, H. Y. (2006). The effects of technology and TQM on the performance of logistics companies. International Journal of Physical Distribution \& Logistics Management, 36(3), 192-209. DOI: 10,1108/09600030610661796

Casadesus-Masanell, R., \& Ricart, J. (2009). From Strategy to Business Models and Onto Tactics. USA: Harward Business School.

Chen, W., Elnaghi, M., \& Hatzakis, T. (2011). Investigating knowledge management factors affecting Chinese ICT firm performance: An integrated KM framework. Information Systems Management, 28(1), 19-29. DOI: 10,1080/10580530,2011.536107

Cragg, P. (2002). Benchmarking information technology practices in small firms. European Journal of Information Systems, 11(4), 267-282. DOI: 10,1057/palgrave.ejis.3000430

Cragg, P. (2008). Identifying key information systems competencies in small firms. Total Quality Management \& Business Excellence, 19(1-2), 29-35. DOI: 10,1080/14783360701601926

Cragg, P., Caldeira, M., \& Ward, J. (2006). Information systems competencies in small manufacturing firms. Working paper, AFIS, NZ: University of Canterbury.

Evans, J. (2011). Quality, Management, Organization and Strategy. USA: South-Western Cengage Learning.

Franke, H. J., \& Pfeifer, T. (1998). Qualitaets-Information Systeme. Wien: Carl Hanser.

Gadatsch, A. (2005). Grundkurs Geschäftsprozess Management. Berlin: Vieweg.

Gordon, I. R., \& McCan, P. (2000). Industrial clusters: Complexes, agglomeration and/or social networks? Urban Studies, 3, 513-532.
Gordon, I. R., \& McCan, P. (2005). Innovation, agglomeration and regional development. Journal of Economic Geography, 5(5), 523-543.

Harton, E., Li, X., Na, K. S., \& Simpson, J. (2010). The role of quality of shared information in interorganizational systems use. International Journal of Information Management, 30(5), 399-407. DOI: 10,1016/j.jiinfomgt.2010,02.007

Iammarino, S., McCann, P. (2006). The structure and evolution of industrial clusters: Transactions, Technology and Knowledge Spillovers. Research Policy, 35(7), 1018-1036. DOI: 10,1016/j.respol.2006.05.004

Laudon, K., \& Laudon, J. (2012). Management Information Systems: Managing the Digital Firm. Twelth Edition. Pearson.

Laudon, K., \& Traver, C. G. (2008). E-Commerce: Business, Technology, Society. Pearson/Prentice Hall.

Leidner, D., Lo, J., \& Preston, D. (2011). An empirical investigation of the relationship of IS strategy with firm performance. Journal of Strategy Information Systems, 20(4), 419-437. DOI: 10,1016/j.jsis.2011.09.001

Martin, E. et all. (2011). Management Information Systems. Prentice Hall.

Mc Fadzean, E., Ezingeard, J., \& Birschall, D. (2011). Information assurance and corporative strategy: A Delphi study of choices, challenges, and developments for the future. Information Systems Management, 28(2), 102-128. DOI: 10,1080/10580530,2011.562127

Mirchandani, D., \& Lederer, A. (2012). Less is more: Information systems planning in an uncertain environment. Information Systems Management, 29(1), 13-25. DOI: $10,1080 / 10580530,2012.634293$

Morosini, P. (2004). Industrial clusters, knowledge integration and performance. World Development, 32(2). 305-326. DOI: 10,1016/j.worlddev.2002.12.001

Ngwenyama, O., \& Morawczynski, O. (2009). Factor affecting ICT expansion in emerging economies: An analysis of ICT infrastructure expansion in five Latin American countries. Information Technology for Development, 15(4), 237-258. DOI: 10,1002/itdj.20128

O'Brien, J., \& Marakas, G. (2011). Management Information Systems. New York: McGraw Hill, IRWIN.

Oukland, J. (2004). Oukland on Quality Management. Burlington, MA: Elsevier.

Peppard, J., \& Ward, J. (2004). Beyond strategic information systems: Towards an IS capability. Journal of Strategic Information Systems, 13(2), 167-194. DOI: 10,1016/j. jsis.2004.02.002 
Prytibok, V., Zhang, X., \& Ryan, S. (2008). Evaluating leadership, IT quality and net benefits in an e-government environment. Information and Management, 45(3), 143-152. DOI: 10,1016/j.im.2007.12.004

Ragovsky, A., Licker, P., \& Gafen, D. (2012). Organizational IT maturity (OITM): A measure of organizational readiness and effectiveness to obtain value form its information technology. Information Systems Management, 29(2), 148-160. DOI: 10,1080/10580530,2012.662104

Republički zavod za statistiku (2012). Statistički Godišnjak Republike Srbije - Upotreba informaciono-komunikacionih tehnologija, 2012. datum preuzimanja: 10,08.2013, http:// webrzs.stat.gov.rs/WebSite/repository/documents/ 00/00/82/35/17_Informacione_tehnologije.pdf,.

Rosenfeld, S. A. (2002). Creating Smart Systems: A Guide to Cluster Strategies in Less Favoured Regions. European Union Regional Innovation Strategies.

Roztocki, N., \& Weistroffer, H. R. (2011). Information technology success factors and models in developing and emerging economies. Information Technology for Development, 17(3), 163-167. DOI: 10,1080/02681102.2011.568220

Sanders, N., \& Premus, R. (2005). Modeling the relationship between firm IT capability, collaboration and performance. Journal of Business Logistics, 26(1), 1-23. DOI: 10,1002/j.21581592.2005.tb00192.x

Scheer, A. W. (1999). ARIS - Business Process Framework. Berlin: Springer.

Stefanović, M. (2005). Renženjering informacionih sistema u Internet okruženju. Neobjavljena doktorska disertacija, Mašinski fakultet Univerzteta u Kragujevcu, Kragujevac, Republika Srbija.
Stefanović, M., Arsovski, S., Arsovski, Z., Aleksic, A., Nestic, S., Rajkovic, D., \& Punosevac, Z. (2012). Integration of virtual an networked organization using server oriented informations. Virtual and Networked Organizations, Emergent Technologies and Tools, Communications in Computer and Information Sciences, 248, 165-175. DOI: 10,1007/978-3-64231800-9_18

Tanriverdi H. (2006). Performance effects of information technology synergies in multibusiness firms. MIS Quarterly, 30(1), 57-77.

Tonchia, S., \& Tramontano, A. (2004). Process Management for the Extended Enterprises: Organizational and ICT Networks. Berlin: Springer, Heidelberg.

Themistocleous, M., Soja, P., \& Rupino da Cunha, P. (2011). The Same, but Different: Enterprise Systems Adoption Lifecycles in Transition Economies. Informaton Systems Management, 28, 223-238. DOI; 10,1080/10580530,2011.585585

Turban, E., Leidner, D., McLaen, E., \& Wetherbe, J. (2006). Information Technology for Management: Transforming Organizations in the Digital Economy. John Willy \& Sons.

Wagner, C. (2004). Enterprise strategy management systems: current and next generation. Journal of Strategic Information Systems, 13(2), 105-128. DOI: 10,1016/j.jsis.2004.02.005

Weill, P., \& Ross, J. W. (2004). IT Governance: How Top Performers Manage IT Decision Rights for Superior Results. Boston: Hardvard Business School Press.

Wieder, B., Booth, P., Matolcsy, Z. P., \& Osimitz, M. L., (2006). The impact of ERP Systems on firms and business process performance, Journal of Enterprise Information Management, 19(1/2), 13-29.

\section{Primljeno 19. avgusta 2013, nakon revizije, prihvaćeno za publikovanje 26. avgusta 2013.}

Zora Arsovski je redovni profesor na Ekonomskom fakultetu Univerziteta u Kragujevcu, uža naučna oblast Statistika i informatika, na nastavnim predmetima: Informacione tehnologije, Informacioni sistemi, Menadžment IS i Strategijsko planiranje IS. Autor je i koautor devet univerzitetskih udžbenika i naučnih monografija, više od 230 radova publikovanih u međunarodnim i nacionalnim naučnim časopisima i konferencijama. Član je uređivačkih i naučnih odbora u međunarodnim naučnim časopisima sa SCI/SSCI liste i liste MNTR Srbije, kao i međunarodnih naučnih konferencija. 


\title{
DETERMINANTS OF THE IMPLEMENTATION OF INFORMATION AND COMMUNICATION TECHNOLOGIES IN CLUSTERS OF ENTERPRISES
}

\author{
Zora Arsovski \\ Faculty of Economics, University of Kragujevac, Kragujevac, Serbia
}

\begin{abstract}
The implementation of Information and Communication Technologies (ICT) in enterprises organized as part of a cluster has its own specifications according to the level and type of relations between enterprises in the cluster. The purpose of this paper is to define determinants for the quality of the ICT implementation in clusters, the research goal being to define and validate the quality models of the implementation of ICT in clusters. Based on the theoretical research of clusters, the quality model for the ICT implementation has been developed and tested to the influences of the determinants of the implementation of ICT, which refer to the level of investments in ICT, quality management, the quality of processes and the level of the implementation of the ICT strategy at the level of the quality of the ICT implementation, with the confirmation of the significance of the stated hypothesis. The results of the research indicate the fact that the level of the quality of the ICT implementation could be predicted with a high accuracy, as well as the influence of the performances of enterprises and the cluster as a whole.
\end{abstract}

Keywords: Information and Communication Technologies, the cluster of enterprises, determinants, quality

JEL Classification: M15, L15, P13, R19 